\title{
Plant Responses to Salt Stress: Adaptive Mechanisms
}

\author{
Jose Ramón Acosta-Motos ${ }^{1}$, Maria Fernanda Ortuño ${ }^{2}$, Agustina Bernal-Vicente ${ }^{1}$, \\ Pedro Diaz-Vivancos ${ }^{1}$, Maria Jesus Sanchez-Blanco ${ }^{2}$ and Jose Antonio Hernandez ${ }^{1, *}$ \\ 1 Fruit Tree Biotechnology Group, Department of Plant Breeding, CEBAS-CSIC, Campus Universitario de \\ Espinardo, P.O. Box 164, E-30100 Murcia, Spain; jram1981@hotmail.com (J.R.A.-M.); \\ tina.cartagena@hotmail.com (A.B.-V.); pdv@cebas.csic.es (P.D.-V.) \\ 2 Irrigation Department, CEBAS-CSIC, Campus Universitario de Espinardo, P.O. Box 164, E-30100 Murcia, \\ Spain; mfortuno@cebas.csic.es (M.F.O.); quechu@cebas.csic.es (M.J.S.-B.) \\ * Correspondence: jahernan@cebas.csic.es
}

Academic Editors: José Palma and Peter Langridge

Received: 22 December 2016; Accepted: 20 February 2017; Published: 23 February 2017

\begin{abstract}
This review deals with the adaptive mechanisms that plants can implement to cope with the challenge of salt stress. Plants tolerant to $\mathrm{NaCl}$ implement a series of adaptations to acclimate to salinity, including morphological, physiological and biochemical changes. These changes include increases in the root/canopy ratio and in the chlorophyll content in addition to changes in the leaf anatomy that ultimately lead to preventing leaf ion toxicity, thus maintaining the water status in order to limit water loss and protect the photosynthesis process. Furthermore, we deal with the effect of salt stress on photosynthesis and chlorophyll fluorescence and some of the mechanisms thought to protect the photosynthetic machinery, including the xanthophyll cycle, photorespiration pathway, and water-water cycle. Finally, we also provide an updated discussion on salt-induced oxidative stress at the subcellular level and its effect on the antioxidant machinery in both salt-tolerant and salt-sensitive plants. The aim is to extend our understanding of how salinity may affect the physiological characteristics of plants.
\end{abstract}

Keywords: adaptive mechanisms; antioxidative metabolism; chloroplast; osmotic regulation; oxidative stress; photosynthesis; salinity; water relations

\section{Introduction}

Salinity is one of the most significant environmental challenges limiting plant productivity, particularly in arid and semi-arid climates [1,2]. Salinity in irrigation water and in soils is one of the major abiotic constraints on agriculture worldwide, and the situation has worsened over the last 20 years due to the increase in irrigation requirements in arid and semi-arid regions such as those found in the Mediterranean area [3-8]. Soil salinity affects about 800 million hectares of arable lands worldwide [9]. A soil is considered to be saline when the electric conductivity (EC) of the soil solution reaches $4 \mathrm{dS} \mathrm{m}^{-1}$ (equivalent to $40 \mathrm{mM} \mathrm{NaCl}$ ), generating an osmotic pressure of about $0.2 \mathrm{MPa}$ and significantly reducing the yields of most crops [9]. As a consequence, ion toxicity, lead to chlorosis and necrosis, mainly due to $\mathrm{Na}^{+}$accumulation that interferes with many physiological processes in plants [10].

The harmful effect of salinity can vary depending on climatic conditions, light intensity, plant species or soil conditions [11]. Depending on the ability of plants to grow in saline environments, they are classified as either glycophytes or euhalophytes, and their response to salt stress differs in terms of toxic ion uptake, ion compartmentation and/or exclusion, osmotic regulation, $\mathrm{CO}_{2}$ assimilation, photosynthetic electron transport, chlorophyll content and fluorescence, reactive oxygen species (ROS) generation, and antioxidant defences [11-14]. Most salinity adaptive mechanisms in plants are 
accompanied by certain morphological and anatomical changes [15]. Glycophytes, which includes most crop plants, cannot grow in the presence of high salt levels; their growth is inhibited or even completely prevented by $\mathrm{NaCl}$ concentrations of $100-200 \mathrm{mM}$, resulting in plant death [16]. Such growth inhibition can even occur in the short term [17]. In contrast, halophytes can survive in the presence of high $\mathrm{NaCl}$ concentrations $(300-500 \mathrm{mM}$ ) because they have developed better salt resistance mechanisms, described above, characteristic of these plants [18,19].

Euhalophythes (plants growing in saline habitats) can cope with the effects of salt stress by developing different resistance mechanisms. These plants can regulate their salt content in the following ways (for more information, please consult [15]):

Salt exclusion: prevents the entry of salts into the vascular system.

Salt elimination: Salt-secreting glands and hairs actively eliminate salts, thus keeping the salt concentration in the leaves beneath a certain threshold.

Salt succulence: If the storage volume of the cells increases progressively with the uptake of salt (as the cells steadily take up water), the salt concentration can be kept reasonably constant for extended periods. Salt redistribution: $\mathrm{Na}^{+}$and $\mathrm{Cl}^{-}$can be readily translocated in the phloem so that the high concentrations arising in actively transpiring leaves can be redistributed throughout the plant.

Euhalophytes can also accumulate salt in their cell sap up to a level at which their osmotic potentials are lower than in the soil solution. In addition to salts, the accumulation of soluble carbohydrates plays an important role in maintaining a low osmotic cell sap potential. The ability of the protoplasm to tolerate high concentrations of salt also depends on the selective compartmentalisation of ions entering the cell. The majority of the salt ions are accumulated in the vacuoles (includer mechanisms).

Salt stress is first perceived by the root system and impairs plant growth both in the short term, by inducing osmotic stress caused by reduced water availability, and in the long term, by salt-induced ion toxicity due to nutrient imbalance in the cytosol [12]. Therefore, the two main threats imposed by salinity are induced by osmotic stress and ionic toxicity associated with excessive $\mathrm{Cl}^{-}$and $\mathrm{Na}^{+}$ uptake, leading to $\mathrm{Ca}^{2+}$ and $\mathrm{K}^{+}$deficiency and to other nutrient imbalances [20]. In addition, salt stress is also manifested as oxidative stress mediated by ROS. All these responses to salinity contribute to the deleterious effects on plants [21-26].

Under saline conditions, plants have to activate different physiological and biochemical mechanisms in order to cope with the resulting stress. Such mechanisms include changes in morphology, anatomy, water relations, photosynthesis, the hormonal profile, toxic ion distribution and biochemical adaptation (such as the antioxidative metabolism response) [18,23,27-29].

\section{Morphological Adaptations of Plants to Salinity}

Irrigation with saline water has different effects on plant growth according to different effects and mechanisms in (1) glycophyte vs. halophyte plants, as well as between different species of the same family and genus, and even between cultivars; (2) different salt levels in the irrigation water and (3) the time of exposure to such stress (short-term assays vs. long-term assays).

Munns [30] concluded that the salts absorbed by plants do not control growth directly, but that they do influence turgor, photosynthesis and/or the activity of specific enzymes. Demonstrating the complexity of salt stress, this author developed a model showing a two-phase effect of salinity on plant growth. Growth is first reduced by a decrease in the soil water potential (osmotic phase) and, later, a specific effect appears as salt injury in leaves, which die because of a rapid increase in salt in the cell walls or cytoplasm when the vacuoles can no longer sequester incoming salts (ionic phase). Munns [30] found that this salt accumulation in the old leaves accelerates their death and thus decreases the supply of carbohydrates and/or growth hormones to the meristematic regions, thereby inhibiting growth. The fact that plant growth is limited by a reduction in the photosynthesis rate and by an excessive uptake of salts affects the production of specific metabolites that directly inhibit growth [31]. 


\subsection{Roots and Aerial Part Morphology}

The anatomy of the root system (length, root diameter, etc.) determines root performance, enabling plants to acquire water and nutrients and thereby increase the replacement rate of plant water lost [32]. Optimum root systems can support shoot growth and improve plant yields, since roots serve as an interface between plants and the soil [33]. A proliferated root system would therefore appear to be better for plants, for it allows them to penetrate deeper layers of soil to acquire water and nutrients [34]. Recent studies, however, have shown that species with other root features, including small roots, can be more advantageous for shoot development [35]. For example, just a few roots in moist soil can provide amounts of water independent of the root number.

Other root characteristics, such as the number and diameter of xylem vessels, width of the root cortex, number of root hairs, and the suberin deposition in both the root exodermis and endodermis, also determine the permeability of roots to water [36,37]. Furthermore, environmental factors in the soil (changes in temperature, lack of $\mathrm{O}_{2}$, mechanical impedance, salinity) can also produce marked impacts on root anatomy. The cell walls of root cells of salinized plants are often unevenly thickened and convoluted [38]. Salts often promote the suberisation of the hypodermis and endodermis in woody tree roots, resulting in the formation of a well-developed casparian strip closer to the root apex, different to that found in non-salinized roots [39]. Furthermore, the morphology of some plants shows their sensitivity to salinity. For example, in avocado trees, the root system is quite superficial and presents low ramification, thus reducing the water and nutrient absorption capacity [40], resulting in a higher sensitivity to soil salinity [41]. These morphological features limit the distribution of this crop to areas where irrigation water is of good quality. Saline water irrigation has also been found to alter the root system morphology of Callistemon citrinus plants [42]. Furthermore, similar responses were found by Álvarez et al. [43] and Álvarez and Sánchez-Blanco [44] in C. citrinus under deficit irrigation, which means that the effect of water stress on C. citrinus root system morphology is very similar to that produced by irrigation with saline water. The same behaviour was also observed in Euonymus japonica plants irrigated with an $\mathrm{NaCl}$ solution and reclaimed water containing different salt concentrations, which decreased the total root length of the plants, more specifically in thin $(\varnothing \leq 0.5 \mathrm{~mm})$ and medium thickness $(0.5<\varnothing \leq 2.0 \mathrm{~mm})$ roots [45]. In other plant species (Picea sp., Pinus banksiana, Portulaca oleracea), Franco et al. [34] and Croser et al. [46] also found an increase in root diameter (hypertrophy) in response to salinity. The greater root density observed in these plants suggests greater robustness and, presumably, a higher accumulation of reserves [34,45,47], which would improve plant resistance to saline situations and speed up the establishment of plants, especially ornamental plants for gardening and landscaping purposes [48,49].

Salinity reduces plant growth through osmotic and toxic effects, and high sodium uptake ratio values cause sodicity, which increases soil resistance, reduces root growth, and reduces water movement through the root with a decrease in hydraulic conductivity [50]. Root hydraulic conductivity in field crops may vary in response to the salt content of the irrigation water applied [36]. In general, the root hydraulic conductivity in plants irrigated with poor quality water tends to decrease. In fact, the effect on root hydraulic conductivity is one of the main factors determining the sustainability of a reclaimed water irrigation system. Normally, root hydraulic conductance is expressed in terms of the whole root dry weight, without taking into account the role of root architecture in the water uptake capacity. Nonetheless, for any given root dry weight value, the amount of fine roots, which determine the root length and surface area, may vary greatly, thus, affecting the water absorption level [51,52].

Moreover, in assays where the grafted technique has been applied, the rootstock properties can affect the plant response to salinity. Salt-tolerant rootstocks alleviate the negative effects of abiotic stress to a greater extent than salt-sensitive rootstocks. Navarro et al. [53] described worse fruit yield and quality in Clemenules mandarin trees grafted on Carrizo (salt-sensitive rootstock) compared with Cleopatra (salt-tolerant rootstock), both irrigated with an $\mathrm{NaCl}$ solution $(30 \mathrm{mM})$. In experiments carried out by Penella et al. [54,55], salt-tolerant rootstocks were found to increase the yield of a commercial pepper cultivar under salinity irrigations. Different nutritional and physiological responses 
were observed, such as ionic regulation, appropriate photosynthetic performance or maintenance of sink strength.

Another possible way to relieve or protect plants from saline stress is to inoculate the roots with arbuscular mycorrhizal fungi (AMF), which are considered to be important bio-ameliorators for saline soils. This role of AMF was studied by Navaro et al. [56] in citrus seedlings inoculated with a mixture of AMF (Rhizofagus irregularis and Funneliformis mosseae), which alleviated the negative effect of salt stress. This protective effect or synergic interaction is even better when it is established with salt-tolerant rootstocks. Other protective effects produced by other AMF (Glomus iranicum var. tenuihypharum) have also been observed on soil and Viburnum tinus irrigated with reclaimed water. Good AMF-soil-plant interactions could make it possible to reuse reclaimed water, particularly when the roots are growing in a saline soil [57].

A general decrease in fresh weight (FW) or dry weight (DW) has been observed in all plant tissues subjected to salt stress, but it is especially noticeable in the aerial part. Different authors have associated the decrease in FW or DW with a reduction in the number of leaves or in leaf abscissions (Table 1). To offer an explanation, some experiments have shown that a specific $\mathrm{Cl}^{-}$build-up in the leaves of salt-stressed plants triggers 1-aminocyclopropane-1-carboxilic acid (ACC) synthesis and its conversion to ethylene with high efficiency, releasing enough hormone to trigger leaf abscission as occurred in citrus leaves and other plants [58-61]. Salt and osmotic stress also promoted the conversion of ACC to ethylene in the halophyte Allenrolfea occidentalis [62]. Other experiments in tomato plants irrigated with high salt concentrations describe that early events during the osmotic phase of salt stress promote leaf senescence prior to the massive accumulation of toxic ions. An indirect effect related to an initial abscisic acid (ABA) accumulation and a decrease in indol-3-acetic acid (IAA) and cytokinin (CK) contents certainly favours the progression of senescence in salinized leaves. However, the ethylene precursor ACC is the major hormonal signal that is temporally correlated with the onset of the oxidative damage, decreases in chlorophyll fluorescence and massive $\mathrm{Na}^{+}$accumulation $[63,64]$.

Another typical response to salt stress described in different papers is a reduction in total leaf area. Indeed, decreased leaf growth is the earliest response of glycophytes exposed to salt stress [16]. The observed reduction in the canopy area may be considered as an avoidance mechanism, which minimises water loss by transpiration when the stomata are closed $[65,66]$. This effect can favour the retention of toxic ions in roots, limiting the accumulation of these ions in the aerial part of the plant $[9,67]$. Under saline conditions cell wall properties change and leaf turgor and photosynthesis rates $\left(\mathrm{P}_{\mathrm{N}}\right)$ decrease, leading to a reduction in total leaf area $[68,69]$. Furthermore, the stem growth (a component of the aerial part) is also normally reduced by high salt concentrations. Decreases in leaf and stem provoke a reduction in all aerial part sizes and in the plant height. All these responses have been described by many different authors (Table 1).

The increase in root to shoot ratio or decrease in shoot to root ratio is a common response to salt stress, related to factors associated with water stress (osmotic effect) rather than a salt-specific effect [70]. A greater root proportion under salt stress can favour the retention of toxic ions in this organ, controlling their translocation to the aerial parts. This response can constitute a typical mechanism of plant resistance/survival under saline conditions [71,72].

High salt concentrations in the irrigation water result in reduced plant growth [9], limiting leaf expansion [73] and changing the relationship between the aerial and root parts [74]. Under high salinity, different plant species have shown a higher dry root mass than shoot dry mass, resulting in an increased root to shoot ratio (Table 1), which is thought to improve the source/sink ratio for water and nutrients under such conditions [75]. Also, a decrease in the shoot to root ratio has also been described by other authors (Table 1). 
Table 1. Effect of salt stress on growth parameters in different plant species.

\begin{tabular}{|c|c|c|c|c|c|}
\hline Plant Species & Salt Treatment & Type of Water ${ }^{a}$ & Time & Parameter & References \\
\hline \multicolumn{6}{|c|}{ (a) } \\
\hline $\begin{array}{l}\text { Pisum sativum cv. Challis } \\
\text { Pisum sativum cv. Granada }\end{array}$ & $30-210 \mathrm{mM}$ & $\mathrm{NaCl}$ & 15 days & Leaf area, leaf FW, leaf DW & [22] \\
\hline Carrizo citrange & $200 \mathrm{mM}$ & $\mathrm{NaCl}$ & 30 days & Leaf abscission & [60] \\
\hline Argyranthemum coronopifolium & $70 \mathrm{mM}$ & $\mathrm{NaCl}$ & 15 days & Leaf area, RGR, NAR, LAR, SLW & {$[76]$} \\
\hline $\begin{array}{l}\text { Limonium latifolium cv. Avignon } \\
\text { Limonium latifolium cv. Beltlaard }\end{array}$ & $140 \mathrm{mM}$ & $\mathrm{NaCl}$ & 20 days & Total DW, shoot DW, Leaf area & [77] \\
\hline Pisum sativum cv. Puget & $70-160 \mathrm{mM}$ & $\mathrm{NaCl}$ & 15 days & Shoot FW, shoot DW & [78] \\
\hline \multicolumn{6}{|l|}{ Pisum sativum cv. Puget } \\
\hline 7 Olea europea L. cvs. & $25-200 \mathrm{mM}$ & $\mathrm{NaCl}$ & 150 days & $\begin{array}{l}\text { Total DW (shoot DW + root DW), Leaf area, } \\
\text { shoot length, root:shoot DW ratio }\end{array}$ & [79] \\
\hline $\begin{array}{l}\text { Carrizo citrange (citrus } \\
\text { genotype) }\end{array}$ & $30,60,90 \mathrm{mM}$ & $\mathrm{NaCl}$ & 28 days & Damage in aerial part, leaf abscission & {$[80]$} \\
\hline $\begin{array}{l}\text { Cistus monspeliensis } \mathrm{L} . \\
\text { Cistus albidus L. }\end{array}$ & $70,140 \mathrm{mM}$ & \multirow{2}{*}{$\mathrm{NaCl}$} & 150 days & $\begin{array}{c}\text { Leaf area, leaf damage } \\
\text { Shoot DW, root DW, RGR, NAR, LAR, LWR, SLA }\end{array}$ & {$[81]$} \\
\hline $\begin{array}{l}\text { Cistus monspeliensis } \mathrm{L} . \\
\text { Cistus albidus L. }\end{array}$ & $\begin{array}{c}\text { Anion surfactant, } \\
\text { Sea-aerosol, AN + SA }\end{array}$ & & 120 days & Total DW, leaf area, leaf number, stem DW, root DW & {$[82]$} \\
\hline Rosmarinus officinalis & $35,70 \mathrm{mM}$ & $\mathrm{NaCl}$ & 180 days & $\begin{array}{l}\text { Leaf DW, total leaf area, stem DW, plant height, } \\
\text { root DW, shoot:root DW ratio }\end{array}$ & [83] \\
\hline 5 perennial herbaceous & $0.8,2,4 \mathrm{dS} \cdot \mathrm{m}^{-1}$ & RW & $\begin{array}{l}90 \text { days (Summer) } \\
90 \text { days (Fall) }\end{array}$ & Visual quality, shoot DW, plant height & {$[84]$} \\
\hline Arbutus unedo & $\begin{array}{r}52 \mathrm{mM}\left(5.45 \mathrm{dS} \cdot \mathrm{m}^{-1}\right) \\
105 \mathrm{mM}\left(9.45 \mathrm{dS} \cdot \mathrm{m}^{-1}\right)\end{array}$ & $\mathrm{NaCl}$ & 112 days & Total DW, leaf area, plant height & [85] \\
\hline $\begin{array}{l}\text { Solanum lycopersicum } \\
\text { L. cv. Moneymaker }\end{array}$ & $100 \mathrm{mM} \mathrm{NaCl}$ & $\mathrm{NaCl}$ & 21 days & Leaf number, leaf FW, leaf area, shoot FW, root FW, root:shoot FW ratio & {$[63]$} \\
\hline 5 Citrus genotypes & $60 \mathrm{mM}$ & $\mathrm{NaCl}$ & 86 days & $\%$ of damaged leaves, leaf abscission & [86] \\
\hline 12 ornamental shrubs & $10,40,70 \mathrm{mM}$ & $\mathrm{NaCl}$ & 120 days & Necrotic leaf percentage, RGR & [72] \\
\hline $\begin{array}{l}\text { Lantana camara } \\
\text { Polygala myrtifolia }\end{array}$ & $\begin{array}{l}2.46 \mathrm{dS} \cdot \mathrm{m}^{-1} \\
5.63 \mathrm{dS} \cdot \mathrm{m}^{-1} \\
4.32 \mathrm{dS} \cdot \mathrm{m}^{-1}\end{array}$ & $\begin{array}{c}\mathrm{NaCl} \\
\mathrm{RW} \\
\mathrm{NaCl}+\mathrm{RW}\end{array}$ & 160 days & Plant dry weight, leaf area, shoot:root ratio, visual quality index & [87] \\
\hline
\end{tabular}


Table 1. Cont.

\begin{tabular}{|c|c|c|c|c|c|}
\hline Plant Species & Salt Treatment & Type of Water ${ }^{a}$ & Time & Parameter & References \\
\hline \multicolumn{6}{|c|}{ (b) } \\
\hline 5 ornamental species & $0.6,4,6,8,12 \mathrm{dS} \cdot \mathrm{m}^{-1}$ & $\mathrm{NaCl}+\mathrm{CaCl}_{2}$ & $\begin{array}{c}180 \text { days }(\mathrm{S}-\mathrm{S}) \\
180 \text { days }(\mathrm{F}-\mathrm{W})\end{array}$ & Visual quality rating, leaf DW, stem DW, root DW, shoot:root DW ratio & [88] \\
\hline Phlomis purpurea & $4 \mathrm{dS} \cdot \mathrm{m}^{-1}$ & $\mathrm{NaCl}$ & 182 days & $\begin{array}{l}\text { Leaf number, total leaf area, stem diameter, shoot DW, plant height, } \\
\text { root DW, shoot:root DW ratio }\end{array}$ & [89] \\
\hline $\begin{array}{l}\text { Viburnum tinus } \\
\text { Metrosideros excelsa }\end{array}$ & $\begin{array}{l}\mathrm{NaCl}\left(2,6 \mathrm{dS} \cdot \mathrm{m}^{-1}\right) \\
\mathrm{B}(1,6 \mathrm{mg} / \mathrm{L})\end{array}$ & $\mathrm{NaCl}+\mathrm{B}$ & 170 days & Leaf fall, plant dry weight, shoot:root ratio & [90] \\
\hline $\begin{array}{l}\text { Echinacea purpurea } \\
\text { Echinacea pallida } \\
\text { Echinacea angustifolia }\end{array}$ & $\begin{array}{c}50 \mathrm{mM}\left(5.50 \mathrm{dS} \cdot \mathrm{m}^{-1}\right) \\
75 \mathrm{mM}\left(7.89 \mathrm{dS} \cdot \mathrm{m}^{-1}\right) \\
100 \mathrm{mM}\left(9.96 \mathrm{dS} \cdot \mathrm{m}^{-1}\right)\end{array}$ & $\mathrm{NaCl}$ & 14 days & $\begin{array}{l}\text { Salt leaf injury index, leaf area, shoot DW, shoot WC }(\%) \text {, } \\
\text { root DW, root WC }(\%)\end{array}$ & [91] \\
\hline Euonymus japonica & $\begin{array}{l}1.7 \mathrm{dS} \cdot \mathrm{m}^{-1}, 4 \mathrm{dS} \cdot \mathrm{m}^{-1} \\
\quad 4 \mathrm{dS} \cdot \mathrm{m}^{-1} \mathrm{RW}\end{array}$ & $\mathrm{NaCl}$ & 140 days & $\begin{array}{l}\text { Leaf DW, leaf number, total leaf area, root DW, total root length, } \\
\text { root:shoot DW ratio, visual characteristic }\end{array}$ & [45] \\
\hline $\begin{array}{l}\text { Evonymus japonica } \\
\text { Viburnum tinus }\end{array}$ & $\begin{array}{l}4 \mathrm{dS} \cdot \mathrm{m}^{-1} \\
4 \mathrm{dS} \cdot \mathrm{m}^{-1}\end{array}$ & $\begin{array}{l}\mathrm{NaCl} \\
\mathrm{RW}\end{array}$ & 140 days & Total biomass DW, leaf number, total leaf area, plant height & [92] \\
\hline Myrtus communis $\mathrm{L}$. & $1.7,4,8 \mathrm{dS} \cdot \mathrm{m}^{-1}$ & RW & 154 days & $\begin{array}{l}\text { Leaf area, Shoot DW, root DW, plant height, } \\
\text { plant compactness (leaf area/height) }\end{array}$ & [93] \\
\hline Callistemon citrinus & $4 \mathrm{dS} \cdot \mathrm{m}^{-1}$ & $\mathrm{NaCl}$ & 56 days & $\begin{array}{l}\text { Leaf DW, stem DW, stem diameter, root DW, total DW, root:shoot DW } \\
\text { ratio, total leaf area, plant height, root morphology parameters, RGR }\end{array}$ & [42] \\
\hline Lawsonia inermis $\mathrm{L}$. & $75,150 \mathrm{mM}$ & $\mathrm{NaCl}$ & 53 days & Total FW, shoot:root DW ratio, RGR & [94] \\
\hline Eugenia myrtifolia & $4,8,12 \mathrm{dS} \cdot \mathrm{m}^{-1}$ & $\mathrm{NaCl}$ & 30 days & $\begin{array}{c}\text { Leaf FW, leaf DW, total leaf area, leaf water content, stem DW, root } \\
\text { DW, root:shoot DW ratio }\end{array}$ & [29] \\
\hline Callistemon laevis & $4 \mathrm{dS} \cdot \mathrm{m}^{-1}$ & $\mathrm{NaCl}$ & 300 days & $\begin{array}{l}\text { Leaf DW, leaf area, stem DW, root DW, plant height, root:shoot DW } \\
\text { ratio, plant compactness (leaf area/ height) }\end{array}$ & [95] \\
\hline Myrtus communis $\mathrm{L}$. & $\begin{array}{l}2.0,5 \mathrm{dS} \cdot \mathrm{m}^{-1} \\
10.0 \mathrm{dS} \cdot \mathrm{m}^{-1}\end{array}$ & $\begin{array}{c}\mathrm{RW} \\
\mathrm{NaCl}\end{array}$ & 90 days & Leaf DW, stem DW, root DW, total DW, root:shoot DW ratio & [6] \\
\hline $\begin{array}{l}\text { Viburnum lucidum } \\
\text { Callistemon citrinus }\end{array}$ & $200 \mathrm{mM}$ & $\mathrm{NaCl}$ & 103 days & $\begin{array}{l}\text { Leaf number, leaf area, shoot DW, apical shoot length, lateral shoot } \\
\text { length, lateral shoots, plant height, root DW, root:shoot DW ratio }\end{array}$ & [8] \\
\hline Verbana bonariensis $\mathrm{L}$. & $200 \mathrm{mM}$ & $\mathrm{NaCl}$ & 2013-2014 & Total plant height, FW of aboveground part, visual score & [96] \\
\hline
\end{tabular}


Gómez-Bellot et al. [45] reported increases in the root to shoot ratio in E. japonica plants irrigated with an $\mathrm{NaCl}$ solution with an electric conductivity (EC) of $4 \mathrm{dS} \mathrm{m}^{-1}$. The use of saline water in C. citrinus plants also slightly decreased aerial growth, increased the root to shoot ratio and improved the root system (increase in root diameter and root density) [42]. Acosta-Motos et al. [28] observed increases in the root to shoot ratio in Myrtus communis plants irrigated for one month with an $\mathrm{NaCl}$ solution with an EC of $8 \mathrm{dS} \mathrm{m}^{-1}$. Over the same stress period, it was necessary to irrigate with an $\mathrm{NaCl}$ solution with a higher EC $\left(12 \mathrm{dS} \mathrm{m}^{-1}\right)$ in order to observe any increases in the root to shoot ratio in Eugenia mirtyfolia plants [29]. Moreover, Acosta-Motos et al. [6] did not observe in the root to shoot ratio in Myrtus communis plants during three months of salt stress using reclaimed waters with ECs of 2 and $5 \mathrm{dS} \cdot \mathrm{m}^{-1}$. However, a significant increase in the root to shoot ratio was observed when an $\mathrm{NaCl}$ solution with an EC of $10 \mathrm{dS} \mathrm{m}^{-1}$ was employed.

\subsection{Visual and Aesthetic Quality}

Another interesting growth parameter linking leaf area with plant height is plant compactness. From an aesthetic and commercial point of view, high values in foliage size in relation to plant height give the plant architecture and compactness that are highly appreciated by nurseries and consumers [44,93]. Also, these changes, induced by salinity, have the potential to improve crop quality by reducing excessive vigour and promoting a more compact habit [49]. However, the level of soil salinity is important, and irrigation with high salt concentrations provokes a decrease in this ratio (leaf area/plant height) due to a reduction in both components which could negatively affect the commercial quality of plants [93,95].

Visual measurements provide a rapid and non-destructive way to diagnose leaf damage from salts. The different classification criteria that have been used for such measurements are described in the following paragraphs. For example, the number of damaged leaves in different Citrus genotype and pea plants was expressed as an injury percentage (\%). When such percentage is equal o above $50 \%$, leaves were considered affected by salinity (chlorosis and/or necrotic lesions) $[80,86,97]$.

Visual quality of five herbaceous perennials was assessed on a scale from 1 to 5 points, where 1 indicated severely stunted growth with more than $50 \%$ of foliage either showing salt damage (leaf necrosis, browning) or dead; 2 indicated somewhat stunted growth with moderate ( $25 \%$ to $50 \%$ ) foliar salt damage; 3 reflected average quality with slight (>25\%) foliar salt damage; 4 meant good quality with acceptable growth reduction and little foliar damage (acceptable in terms of landscape performance); and 5 indicated excellent plants with vigorous growth and no foliar damage [84].

Bañón et al. [87] and Salachna and Piechocki [96], on the other hand, used a visual quality index to evaluate the aesthetic quality of plants at the end of their experiment. The index ranged from 1 (non-commercial) to 5 (very good quality), is based on the amount of leaf discolouration, leaf necrosis, defoliation and flowering.

In other experiment carried out by Valdez-Aguilar et al. [88], five ornamental species were visually rated to determine their ornamental attributes using a scale from 1 (poor quality, leaf bronzing higher than $75 \%$ or dead plants) to 5 (best quality, no leaf bronzing). Moreover, the same authors determined the visual quality rating using the piece-wise linear response function as proposed by Van Genuchten [98]. This function contains the following three independent parameters: (1) the non-saline control quality rate; (2) the salinity threshold (the maximum salinity without a quality rate reduction as compared with non-saline conditions); and (3) the slope (the fractional quality rate decline per unit increase in salinity beyond the threshold).

Sabra et al. [91] studied the salt injury index in three different Echinacea species. To measure this parameter, they assessed the visual appearance of the leaves using a five-point scale according to the severity of necrotic tissues and the number of injured plants, as previously described [99]. The scale was as follows: level 1 (no necrotic areas); level 2 ( $1 \%-25 \%$ necrotic areas); level 3 ( $26 \%-50 \%$ necrotic areas); level 4 ( $51 \%-75 \%$ necrotic areas); and level 5 (76\%-100\% necrotic areas or death of the plant). 
Finally, Gómez-Bellot et al. [45] studied the percentage of plants affected according to visible characteristics linked to quality in E. japonica plants irrigated with water from different sources. These plants were classified into the following four groups: percentage of plants in acceptable conditions (PAC); percentage of plants with dry branches (PDB); percentage of plants in ideal conditions (PIC) and; percentage of dry plants (DP).

\subsection{Growth Indexes Used with Salinity Studies}

To observe the effects of salinity on plant morphology, many authors have studied different growth indexes such as relative growth rate (RGR), net assimilation rate (NAR), leaf area ratio (LAR), specific leaf area (SLA) and leaf weight ratio (LWR), according to Beadle [100], as follows:

$$
\begin{gathered}
\mathrm{RGR}=(\ln \mathrm{W} 2 / \mathrm{W} 1) /(\mathrm{t} 2-\mathrm{t} 1) \\
\mathrm{NAR}=[(\mathrm{W} 2-\mathrm{W} 1) /(\mathrm{A} 2-\mathrm{A} 1)][(\ln \mathrm{A} 2 / \mathrm{A} 1) /(\mathrm{t} 2-\mathrm{t} 1)] \\
\mathrm{LAR}=[(\mathrm{A} 2-\mathrm{A} 1) /(\mathrm{W} 2-\mathrm{W} 1)][(\ln \mathrm{W} 2 / \mathrm{W} 1) /(\ln \mathrm{A} 2 / \mathrm{A} 1)] \\
\mathrm{SLA}=[(\mathrm{A} 2-\mathrm{A} 1) /(\mathrm{WL} 2-\mathrm{WL} 1)][(\ln \mathrm{WL} 2 / \mathrm{WL} 1) /(\ln \mathrm{A} 2 / \mathrm{A} 1)] \\
\mathrm{LWR}=[(\mathrm{WL} 2-\mathrm{WL} 1) /(\mathrm{W} 2-\mathrm{W} 1)][(\ln \mathrm{W} 2 / \mathrm{W} 1) /(\ln \mathrm{WL} 2 / \mathrm{WL} 1)],
\end{gathered}
$$

where $\mathrm{W}$ is the total dry weight, $\mathrm{t}$ is the time, $\mathrm{A}$ is the total leaf area, $\mathrm{WL}$ is the total dry weight of leaves, and 1 and 2 are the beginning and end of a period (stress or recovery), respectively. Generally, high salt concentrations considerably reduce the RGR values (Table 1).

To give an example, Cassaniti et al. [71] studied the effect of $\mathrm{NaCl}$ on 12 widely cultivated ornamental shrubs in order to classify the plants. The following salt concentrations were used for irrigation over a period of 120 days: 10, 40 and $70 \mathrm{mM}$. The effect the salt had on growth depended on the species and salt concentration employed. Based on the results, the plants were distributed into the following four groups, using the decrease in RGR as criterion: (1) salt tolerant species, RGR decrease of less than $25 \%$; (2) moderately salt tolerant species, RGR decrease between $25 \%-50 \%$; (3) moderately salt sensitive species, RGR decrease between $50 \%-75 \%$; and (4) salt sensitive species, RGR decrease greater than $75 \%$.

Other papers have observed good correlation between RGR and LAR, but not with NAR, showing that leaf expansion is the growth limiting factor [101]. Other authors, however, have described a correlation between RGR and NAR, but not with LAR, indicating that photosynthesis could be the limiting factor and that a reduction in RGR may be due to a direct effect of salt stress on stomatal conductance and/or the photosynthetic apparatus [69,81,102].

Finally, high salt concentrations can produce a significant reduction in NAR and LAR values, indicating that both the photosynthetic rate and leaf expansion act as limiting factors in plant growth [76]. Decreases in leaf area linked to salinity directly affect the specific leaf area (SLA). However, salinity can increase the biomass fraction in leaves (LWR), associated with lower values in dry stem weight. Plants showing this behaviour are able to maintain their leaf characteristics and bloom well in spite of their total decrease in biomass [69].

\section{Leaf Anatomy and Ultrastructure Changes in Leaves under Salinity}

Studying the changes produced in leaf anatomy is an appropriate way to study abiotic stress situations, including salt stress $[28,29,94,103]$. A pioneer assay in this field was carried out by Longstreth and Nobel [104]. These authors studied the effect of salinity on three plants with different responses to salt stress (Phaseolus vulgaris, salt-sensitive; Gossypium hirsutum, moderately salt-tolerant; and Atriplex patula, salt-tolerant). To study changes in leaf anatomy, these authors measured different parameters, such as epidermal, mesophyll and leaf thickness; the length and diameter of palisade cells; the diameter of spongy cells; the surface area of mesophylls per unit of leaf surface area; the ratio of 
mesophyll cell surface area to leaf surface area; and leaf succulence. The salt-tolerant specie, Atriplex patula, irrigated with different $\mathrm{NaCl}$ solutions $(0.05,0.1,0.2,0.3$ and $0.4 \mathrm{M})$, showed more leaf thickness due to an increase in epidermal and mesophyll thickness. Finally, major increases were observed in the succulence values. Opposite effects were observed in the other two species that were less tolerant to salt irrigation.

Romero-Aranda et al. [105] studied anatomical disturbances produced by chloride salts ( $\mathrm{KCl}$, $\mathrm{ClCa}_{2}, \mathrm{NaCl}$ ) in both sensitive (Carrizo citrange) and tolerant (Cleopatra mandarin) citrus varieties. The salt-induced declines in $\mathrm{P}_{\mathrm{N}}$ were linked to changes in leaf anatomical properties, such as the increase in leaf thickness and the lower area/volume ratio of mesophyll cells. Salinity also increased the succulence of leaves and reduced the intercellular air spaces, the surface/volume ratio of cells and tissue density. These results suggest that in salinized citrus, the increase in leaf thickness, in combination with several metabolic components such as chloride overloading, low $\mathrm{Mg}^{2+}$, stomatal closure and chlorophyll loss, may contribute, among other factors, to the decline in photosynthesis. In addition, the contribution of leaf anatomical disturbance to the decline in net $\mathrm{CO}_{2}$ assimilation is also dependent on the degree of genotype tolerance. On the other hand, a recent work carried out by Franco-Navarro et al. [106] proposes that chloride $\left(\mathrm{Cl}^{-}\right)$plays a beneficial role as a nutrient in tobacco plants. These plants improve their leaf water balance with a decrease in transpiration associated with a reduction in stomatal conductance, which results in a decrease in water loss, an increase in the photosynthetic rate and improved water use efficiency. In addition, $\mathrm{Cl}^{-}$in particular produces anatomical changes in the leaves, increasing their size and succulence.

Navarro et al. [85] observed the anatomical changes associated with salt stress in Arbutus unedo leaves by optical microscopy in semi-thin sections. A comparison of control plants with saline-treated plants showed that the cell size of the first layer of palisade cells was not significantly altered. However, the cell size of the second layer of palisade cells significantly increased in parallel with the levels of salinity $(0 \mathrm{mM}, 52 \mathrm{mM}$ and $105 \mathrm{mM} \mathrm{NaCl})$. These authors also noticed an important decrease in the intercellular spaces in the spongy mesophyll in both saline treatments compared with control leaves, and this decrease affected the stomatal and mesophyll conductance to $\mathrm{CO}_{2}$.

Fernández-García et al. [94] studied the ratio of leaf mass to leaf area (LSM) in henna plants irrigated with high salt concentrations. LSM is a key trait in plant growth and an important indicator of plant strategies to salt stress. Salt-treated henna plants respond to low and high salinity by increasing LSM. The same authors also noticed that high salt levels increased leaf thickness and suggested that the increase in leaf thickness and therefore in LSM in salt-stressed henna plants may imply a greater investment in assimilatory tissue as a strategy to maximise the photosynthesis potential.

Acosta-Motos et al. [28,29] studied leaf anatomical changes in Myrtus communis and Eugenia myrtifolia plants subjected to an $\mathrm{NaCl}$ solution of $8 \mathrm{ds} \cdot \mathrm{m}^{-1}$ for the same exposure time (30 days). In myrtle, no significant changes were observed in the palisade parenchyma, but a decrease in spongy parenchyma and an increase in intercellular space were found. In eugenia leaves, the same anatomical changes were observed. In addition, eugenia leaves displayed a remarkable increase in palisade parenchyma. These traits in eugenia plants improve $\mathrm{CO}_{2}$ diffusion, making it easier for $\mathrm{CO}_{2}$ to reach the chloroplasts, which have a greater presence in palisade parenchyma. These alterations can protect and improve the $\mathrm{P}_{\mathrm{N}}$ performance in eugenia plants, especially in a situation of reduced stomatal aperture (Figure 1). Similar results were observed by Gómez-Bellot et al. [107] in Viburnum tinus L. plants irrigated with treated wastewater. The leaf thickness of these plants increased due to an increase in the palisade parenchyma, thus maximising the photosynthesis potential in a saline situation.

Similar anatomical changes were also described by Rouphael et al. [108] in zucchini squash grown under saline conditions. In this experiment salt stress was accompanied by an increase in mesophyll thickness due to increased intercellular spaces. Such anatomical modifications in the leaves of salt stressed zucchini squash plants agree with previous findings in the ornamental shrubs Myrtus communis and Eugenia myrtifolia [28,29]. However, despite these modifications, zucchini squash plants 
supplied with $\mathrm{NaCl}$ had sharply reduced leaf $\mathrm{P}_{\mathrm{N}}$. Ultimately, salt stress induced decreases in $\mathrm{P}_{\mathrm{N}}$ in zucchini squash as well as in eugenia and myrtle plants.

\section{Control $\quad 8 \mathrm{dS} \mathrm{m}^{-1} \mathrm{NaCl}$}

Eugenia

Myrtle

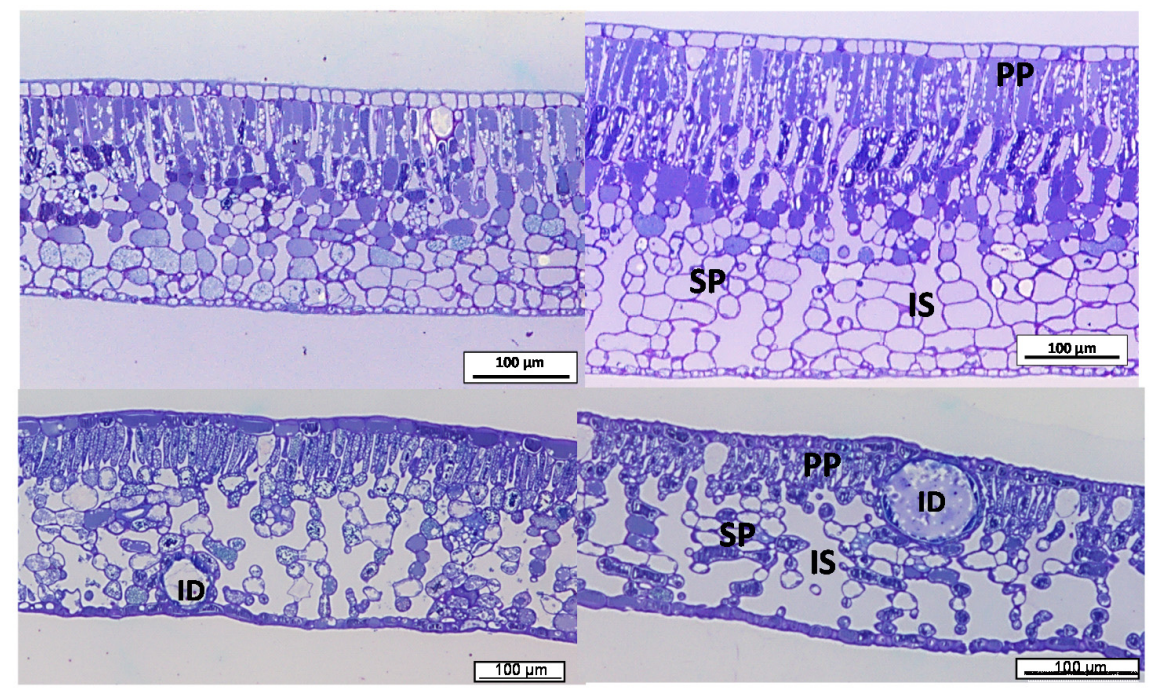

Figure 1. Light microscopy images showing the effect of $\mathrm{NaCl}$ on the percentage of area occupied by palisade parenchyma (PP), spongy parenchyma (SP) and intercellular spaces (IS) in leaves from E. myrtifolia and M. communis plants after 30 days of $\mathrm{NaCl}$ treatment. ID: idioblast. The increase in palisade parenchyma and intercellular spaces and decrease in spongy parenchyma can improve the $\mathrm{CO}_{2}$ diffusion, making it easier for $\mathrm{CO}_{2}$ to reach the chloroplasts, which are present in a greater proportion in the palisade parenchyma. Partially reproduced from [28,29].

In general, these anatomical changes parallel to the observed decreases in $P_{N}$ are not as great as the changes observed in stomatal conductance (gs). Therefore, under salt stress situations, high $\mathrm{P}_{\mathrm{N}} / \mathrm{gs}$ ratios (also expressed as intrinsic water use efficiency, WUEi) indicate that the leaves (more specifically, the chloroplasts), try to maintain high photosynthetic performance despite significant stomatal closure.

Damage to the chloroplast is an important aspect of the effect of salinization on leaf cells. The ultrastructure of the peroxisomes and mitochondria are also affected by salinity, albeit with less intensity. Under salinity conditions, $\mathrm{NaCl}$-sensitive pea plants have been found to show leaf mitochondria with a lower number of cristae and lower electron density than the mitochondria of $\mathrm{NaCl}$-tolerant pea plants [21].

The main changes that have been observed in the chloroplast of salt-irrigated plants are as follows:

(1) Changes in the number and size of chloroplasts and in the starch content.

(2) Disorganised chloroplast membranes.

(3) Changes in the number and size of plastoglobuli.

(4) Loss of the envelope and disorganisation of grana and thylakoids.

The effect of salinity on leaf ultrastructure can vary in relation to the tolerance of the plant to $\mathrm{NaCl}$, as described in two rice (Oryza sativa L.) varieties [109]. The sensitive rice variety (Amber) showed differences in the integrity of the chloroplast compared with the tolerant variety (IR2153). Concretely, in response to high $\mathrm{NaCl}$, most of the chloroplasts in the Amber variety showed signs of damage. In contrast, the chloroplasts in the tolerant variety IR2153 did not show any effect of salinity. This response correlated with a $30 \%$ decline in $\mathrm{P}_{\mathrm{N}}$ in Amber, whereas no significant change in $\mathrm{P}_{\mathrm{N}}$ was observed in IR2153.

The effect of $\mathrm{NaCl}$ on leaf chloroplast ultrastructure was studied in two different pea cultivars with different levels of sensitivity to $\mathrm{NaCl}$, one salt-sensitive (cv. Challis) and the other relatively 
salt-tolerant (cv. Granada), up to $70 \mathrm{mM} \mathrm{NaCl}$ [22]. NaCl produced a disorganised tylakoidal structure in both pea cultivars. These authors described two different chloroplast populations that showed different densities in Percoll gradients. By electron microscopy, the authors noticed that the higher density band contained higher starch contents than the low-density band. Salinity affected the two chloroplast bands differently, and even the high-density band disappeared in the salt-treated sensitive plants [22]. In the NaCl-tolerant plants, salinity reduced the diameter of the chloroplasts from the low-density band. In both cases, an increase in the number and size of plastoglobuli was observed by the effect of $\mathrm{NaCl}$, and the change was more evident in the tolerant plants [22]. Plastoglobuli are ubiquitous in chloroplasts and chromoplasts. Under different stress situations, plastoglobules increase as the thylakoids break down [110].

In the same study referred to above, Hernández et al. [22] noted that $\mathrm{NaCl}$ had different effects on the starch content in salt-sensitive and salt-tolerant pea plants. Whereas the percentage of starch decreased in both chloroplast populations in tolerant plants, no change occurred in sensitive plants. These data suggested that tolerant plants could use starch for different physiological processes to cope with the salt stress challenge [5].

Furthermore, as shown by Morales et al. [76], Argyranthemum coronopifolium is also sensitive to high salt concentrations. These authors found that salinity did not induce variations in the number of chloroplasts in these plants, although the size of the chloroplasts increased significantly in palisade and mesophyll cells due to an increase in starch content that was more evident in palisade parenchyma than in mesophyll tissue. The increased accumulation of starch in the leaf chloroplast in saline conditions could be explained by a lower accumulation of hexoses and sucrose and greater sucrose-phosphate synthase activity, leading the triose-phosphate pathway toward starch synthesis, and/or to damage of the enzymes involved in starch degradation via changes in the ionic composition in the chloroplast [111,112]. The different leaf photosynthetic rate values found by Morales et al. [76] would explain the differences in chloroplast size and starch accumulation found between palisade and mesophyll parenchyma.

Sánchez-Blanco et al. [82] studied the differences of the effects of simulated sea aerosol on the chloroplast ultrastructure of two rock-rose plants, White-leaf-rock-rose (Cistus albidus L.) and Montpellier rock-rose (Cistus monspeliensis L.). Transmission electron microscopy observation of Montpellier rock-rose control leaves showed well-organised chloroplasts with abundant starch grains and a structured cytoplasm. In plants treated only with surfactant, the ultrastructure of the organelles was not altered. When leaves were treated with sea aerosol only, the structure of some chloroplasts was altered, the starch grain decreased significantly and in some cases even disappeared, and in some of the chloroplasts, the thylakoid membranes appeared to be swollen. In leaves treated with sea aerosol plus surfactant, the chloroplasts showed the same alterations as plants treated with sea aerosol only. The substantial reduction in starch grains could be due to the fact that mesophyll cells from C. monspeliensis L. use soluble sugars to contribute to the osmotic adjustment induced by saline stress, which makes them more tolerant to salinity than C. albidus L. plants.

Navarro et al. [85] studied the effects of $\mathrm{NaCl}$ on the leaf ultrastructure of $\mathrm{NaCl}$-sensitive Arbutus unedo plants. The chloroplast ultrastructure was altered and $\mathrm{P}_{\mathrm{N}}$ was reduced by salinity. Furthermore, the number of plastoglobuli was significantly higher and the thylakoids were more dilated in the saline-treated leaves than in the control leaves.

More recently, Fernández-García et al. [94] observed changes in the ultrastructure of chloroplast from henna plants (Lawsonia inermis L.) irrigated with high salt levels. The control plants showed an abundant presence of starch grains and well-developed grana. Nevertheless, the chloroplast of the palisade cells had more dilated thylakoids and bigger starch grains in salt-treated plants. Moreover, the chloroplasts of the spongy mesophyll were highly altered, showing poorly developed and dilated thylakoids [94]. 


\section{Water Relations, Gas Exchange and Osmotic Regulation and Related Salt Tolerance Mechanisms}

Plant-water relations explain the behaviour of plants in terms of how they control the hydration of their cells, which has important implications in the physiological and metabolic processes that determine the quantity and quality of plant growth [113]. Plants usually live in two different environments, the soil and the atmosphere, and these two media do not always behave in a coordinated manner. The evaporative demand of the atmosphere is practically continuous, whereas the water supply by rain or irrigation can be insufficient. Most of the water absorbed by plants from the soil is lost to the atmosphere by transpiration. In this situation, a hydraulic gradient is established in the xylem, which results in water flow from the roots to the leaves. This water movement is proportional to a driving force and in inverse proportion to resistance encountered through the soil-plant system. Transpiration creates the internal conditions under which water is absorbed by the root system and transported to the canopy [114]. As water is lost by transpiration, leaf water potential and the pressure in the xylem are reduced. Water transpiration from leaves is primarily controlled by stomata, but sustained transpiration, without sufficient replenishment, leads to progressive dehydration (loss of leaf turgidity). The degree of dehydration of plants depends on many factors: the climate and environment, the characteristics of the canopy, the growth stage of the plant, and, especially, the irrigation regime and water quality. In well-watered plants, transpiration represents the most effective means of leaf cooling [113]. Under water deficit, with the stomata closed, transpiration only occurs through the cuticle and the plant canopy. As a result, temperature tends to rise, which causes an increase in stomatal resistance to transpiration and an increase in the rate of tissue respiration. Under these conditions, photosynthetic capacity is limited and the plant uses its own photo-assimilates, resulting in decreased growth.

It is well known that the accumulation of salts in the root zone causes a decrease in osmotic potential and, consequently, a decrease in the water potential, diminishing the water available to the root zone [34,82]. Furthermore, when salts are present in the soil solution, they cause nutrient imbalances, inducing inhibition in the uptake of essential nutrients from the roots [114-117]. Other consequences of salt stress include metabolism alteration, such as hormonal changes, reduced enzyme activity and impaired photosynthesis $[10,118]$. In this way salinity affects plant establishment, growth and development, leading to a significant loss in productivity [45,79,89,92,119-121].

Nevertheless, the response to salinity varies depending on the stage of plant growth; the growing conditions, including climatic and soil factors; the agronomic and irrigation management practices; and the degree of tolerance of the species (glycophytes vs. halophytes) $[42,45,77,92,120,122]$, which can even vary among the different cultivars of the same species $[77,82]$.

Early responses to water and salt stress are very similar, because salts hinder the absorption of water through the root system due to the osmotic effect [123]. However, different plant responses have been observed in the long term [42]. Previous studies have concluded that salt-tolerant plants are not necessarily drought-tolerant plants and vice versa [121,124]. Specific mechanisms for salt avoidance either minimise the entry of salt into the plant or decrease the concentrations of salt in the cytoplasm of the cells. While halophytes have both types of mechanisms (salt exclusion and salt compartmentalisation in vacuoles), enabling them to grow for long periods of time, most glycophytes have a low ability to exclude salt and thus accumulate toxic ions in the leaves with the transpiration flow $[10,15]$.

A plant exposed to salinity balances its water potential by losing water, which induces a decrease in osmotic potential and turgor. This creates chemical signals that can trigger subsequent adaptive responses $[125,126]$. During the adjustment process, an accumulation of organic and inorganic solutes that reduce cellular osmotic potential [10] and a reduction in the hydraulic conductivity of the membranes occurs, possibly by decreasing the number of water channels (aquaporins) [127]. Once turgor is recovered, growth can be restored [128]. 


\subsection{Effects of Salinity on Leaf Water Relations and Gas Exchange}

Across the soil-plant-atmosphere continuum, water flow is favoured by the gradient between soil water potential and leaf water potential. Whole plant hydraulic conductivity and individual conductance components are considered the main factors that control the movement of water through the soil-plant system and have been linked with plant transpiration and other physiological processes related with transpiration [129-132]. Differences in root hydraulic conductance may cause differences in water transport from soil to plant, influencing the leaf water status and therefore in the growth and other physiological responses of the plant [133].

As far as plant water status is concerned, plants under saline or deficit irrigation exhibit slight dehydration, as indicated by lower water potential, due to higher difficulty in taking up water from the substrate or less available water in the substrate $[89,134]$. The most negative values for leaf water potential and stem water potential have been found in plants submitted to both water stress and salinity, as both passive dehydration and salt accumulation contribute to lowering the leaf water potential [135]. According to Álvarez and Sánchez-Blanco [42,44], stem water potential measured at midday is a good indicator of stress resulting from deficit irrigation or salinity. In addition, the difference between stem water potential and leaf water potential measured simultaneously in the same plant can be an indicator of the instantaneous shoot transpiration level [44].

Recently, Pérez-Pérez et al. [136] have studied the agronomic (fruit quality, yield, vegetative growth) and physiological (plant water status, gas exchange parameters, leaf mineral nutrition) responses in lemon trees using two different irrigation strategies: regulated deficit irrigation (RDI) and regulated saline irrigation (RSI). Their conclusions determine that RDI could be the best irrigation option for long water restriction periods. On the other hand, RSI would be successful for a period of only one year.

Salinity disturbs a plant's water relations due to a decreased availability of water from the soil solution as a result of lowered osmotic potential triggered by the toxic effects of the sodium and chloride ions [12]. Accordingly, an increase in resistance to water flow from soil to plant under salinity has been observed in many species $[85,89]$. For example, root hydraulic resistance has been found to increase in salt-stressed plants such as Euonymus japonica, Phlomis purpurea, and Rosmarinus officinalis, in which the lowest leaf water potential values have been recorded $[45,83,89]$.

Salinity also causes a decrease in stomatal conductance and evaporation, and, as a result, smaller amounts of toxic ions are delivered to the root surface and into the plant. Recent research has confirmed that stomatal closure at the beginning of salinity exposure can contribute to a decline in the flow of toxic ions within the transpiration stream [137-139]. Decreases in stomatal conductance due to salinity have been found in several different plant species [45,90].

There is mounting evidence that stomatal regulation of vapour loss is extremely sensitive to short-term salt stress [140-142]. Previous comparisons of water relations in some barley cultivars with different drought resistance levels showed that lower stomatal conductance and transpiration at the beginning of salt exposure contributed to higher salt tolerance in terms of improved extension growth and less accumulation of toxic ions [139]. Other authors have reported that stomatal responses to different abiotic stress are probably regulated by root signals, as occurs in drying and re-wetting soils $[143,144]$. Stomatal closure in salt-stressed plants may be induced by the accumulation of abscisic acid $[139,145,146]$. However, Tardieu and Simonneau [147] concluded that the maintenance of water relations may be linked to an interaction between both chemical and hydraulic information.

Koyro [13] suggest that reductions in stomatal conductance represent an adaptive mechanism for coping with excessive salt, reducing the salt load of leaves and helping increase longevity by maintaining salts at subtoxic levels for longer than would occur if transpiration rates were not diminished.

Under salinity, some plants, such as Rosmarinus officinalis, develop tolerance and avoidance mechanisms. These mechanisms are based on stomatal closure and a reduced leaf area, in order to minimise water loss via transpiration [83]. Other resistance mechanisms include the development of 
osmotic adjustments, mainly involving the intake of inorganic solutes from the soil under salt stress situations to facilitate the maintenance of leaf turgor $[69,123,148]$.

Decreases in stomatal conductance are one of the causes of photosynthesis $\left(\mathrm{P}_{\mathrm{N}}\right)$ decline, although photoinhibition or increases in mesophyll resistance may also play an important role when stress is more severe or prolonged $[149,150]$. Such changes could delay plant recovery at the onset of the autumn or even cause permanent damage. Long-term reduced net $\mathrm{CO}_{2}$ assimilation rates accompanying salinity have been attributed to stomatal closure, a decline in photosynthetic pigment content and concurrent non-stomatal factors (e.g., reduced protein concentrations) [92,151]. A decrease in $\mathrm{P}_{\mathrm{N}}$ due to salinity stress has also been reported in many other plant species, such as Viburnum tinus, a salt-sensitive species [90], and Alternathera bettzickiana, a halophytic ornamental plant [152].

There must be a level of stress that triggers a stomatal opening control to prevent loss of water and maintain $\mathrm{CO}_{2}$ fixation without an excessive decrease in productivity or plant growth. Thus the ratio of stomatal opening and the level of photosynthesis (photosynthesis efficiency or intrinsic water use efficiency, WUEi, [153]) are indicators of tolerance to osmotic stress. In P. purpurea plants submitted to a salt treatment, both $\mathrm{P}_{\mathrm{N}}$ and gs decreased in a similar way. On the other hand, E. myrtifolia and C. citrinus plants submitted to salt stress were able to increase their WUEi throughout most of the growing season, i.e., the plants maintain higher $\mathrm{P}_{\mathrm{N}}$ levels despite reduced stomatal opening $[7,42]$. This response agrees with the findings of Munns and Tester [9] and James et al. [154], who suggested that rates of $\mathrm{P}_{\mathrm{N}}$ per unit leaf area in salt-treated plants often remain unchanged, even though gs is reduced.

When drought and heat co-occur, stomatal closure and decreased transpiration, associated with high WUEi, may lead to a dramatic increase in leaf temperature (up to $7^{\circ} \mathrm{C}$ above air temperature) [155]. If this situation remains for long periods of time, leaf photodamage and/or xylem embolism may occur, leading to severe defoliation and plant death [156].

Variations in stomatal opening affect transpiration, which is a mechanism that leaves use for cooling. Accordingly, a decrease in stomatal conductance leads to an increase in leaf temperature. Under salinity conditions, as osmotic stress increases, transpiration rates and the resulting leaf latent-heat flux decrease, leading to an increased surface temperature that consequently increases the difference in temperature between salt-stressed and control plants. Accordingly, Halim et al. [157], Gerard et al. [158] and Sirault et al. [159] reported that stomatal closure in saline-stressed plants induced an increase in canopy foliage temperature. Furthermore, canopy temperature measurements in sorghum plants were found to be sensitive enough to indicate differences across the salinity treatments when soil moisture was uniform for several days following irrigation. The results of several studies have demonstrated that canopy temperature or thermal indices may be useful indicators of osmotic effects due to salt stress on myrtle, sorghum and euonymus plants $[6,158,160]$.

\subsection{Plant Osmotic Regulation}

The accumulation and compartmentalisation of toxic ions and/or compatible solutes to increase osmotic tolerance are among the mechanisms involved in salt tolerance [161]. The osmotic regulation process of stomatal opening occurs via the movement of solutes, called osmolytes, which influence water movement between the cells. This water movement has several purposes linked to cell hydration inside plants, such as stomatal opening and higher water absorption via the root system. Several compounds that work in the osmotic regulation of plants are well known: carbohydrates (sucrose, sorbitol, mannitol, glycerol, arabinitol, pinitol) [162]; nitrogen compounds (proteins, betaine, glutamate, aspartate, glycine, proline, choline, putrescine, 4-gamma aminobutiric acid) [163]; and organic acids (malate and oxalate). Common responses in species exposed to saline or drought stress are an increase in osmotic adjustment, changes in the cell wall elasticity, decrease in saturation weight/dry weight ratio and increase in the percentage of water apoplastic, which minimizes the saline effects by maintaining the foliar turgidity. According to Navarro et al. [123], Zheng et al. [164] and Suárez [165] osmotic and/or elasticity adjustment result in the turgor loss point being reached at a lower leaf water potential 
and at a lower relative water content. The degree of osmotic adjustment differs among plant species. Furthermore, the degree of osmotic adjustment can also be affected by the speed at which the stress is imposed and the age of the plant, among other factors [13,14].

Limited osmotic adjustment has been observed in Mediterranean ornamental plants submitted to saline stress $[89,123]$. C . citrinus, for example, may behave as a typical $\mathrm{Cl}^{-}$includer (accumulator), compartmentalising $\mathrm{Cl}^{-}$within the leaf vacuoles, where it may be used as an osmolyte to lower the osmotic potential necessary for the maintenance of leaf turgor [13]. Such osmotic adjustment made it possible for $C$. citrinus plants to maintain turgor potential throughout saline treatment, despite only moderate osmotic adjustment ( $0.2 \mathrm{MPa})$. This behaviour and the osmotic adjustment values observed are within the range of those reported in other studies on Mediterranean ornamental plants submitted to saline stress $[69,123,148]$.

Moderate salinity did not change the cell wall elasticity of the shoot tissue in C. laevis, however, suggesting that elastic adjustment did not play a role in the adaptation mechanism, although some changes in the cell wall composition may have occurred (such as in cell wall thickness and chemical composition, for example), which could have contributed to the decrease in growth recorded in this species in response to salt stress $[166,167]$.

Among the organic osmolytes, proline (Pro) and glycine-betaine (GB) are the most important and efficient compatible solutes [11]. In addition to acting as an osmoprotectant, Pro has been reported to have antioxidant properties, and it can act as a molecular chaperone to protect the structure of biological macromolecules during dehydration, thus conferring plant tolerance to environmental stresses $[11,168]$. In plants, proline synthesis is mainly catalysed by $\Delta$-1-pyrroline-5-carboxylate synthetase (P5CS; EC 2.7.2.11/1.2.1.41), which converts glutamate into $\Delta$-1- pyrroline-5-carboxylate (P5C) in the cytoplasm or chloroplast. P5C reductase (P5CR) further reduces P5C to proline [169]. In addition, proline may be also synthesised in mitochondria from ornithine by ornithine $\delta$-aminotransferase (OAT; EC 2.6.1.13), catalysing the formation of P5C, which is further reduced to proline by P5CR. Proline degradation, occurring in the mitochondria, is mediated by the action of proline dehydrogenase (ProDH; EC 1.5.99.8), which produces P5C from proline, and of P5C dehydrogenase, which converts P5C to glutamate [170].

In general, salt-tolerant species accumulate Pro after a salt-stress challenge. For example, Eugenia myrtifolia L. plants showed a salt-tolerant response when treated with $8 \mathrm{dS} \cdot \mathrm{m}^{-1} \mathrm{NaCl}$ for 30 days, as observed by the effect in plant growth, and this response correlated with a $20 \%$ increase in leaf Pro contents [30]. Furthermore, the application of Pro and/or GB to salt-stressed rice plants improved plant growth [171].

Glycine betaine is synthesised and accumulated under a variety of abiotic stresses, and it acts as an osmolyte to protect PSII during salinity [172]. It can also protect the integrity of membranes and the activity of enzymes against osmotic stress [173].

Salt stress is also associated with the toxic effect produced by the absorption of salt ions that can cause damage to the various subcellular organelles, mainly mitochondria and chloroplasts, when accumulated to high levels in the cells. These ions can also have a negative effect on the different enzymatic activities. Most unwanted ions in the plant are compartmentalised in the vacuoles, where they cease to be directly harmful, and only those that fall outside the vacuoles cause saline damage. Tolerance mechanisms in salt stress are therefore strategies aimed at the inclusion and exclusion of toxic ions.

The exclusion of salts can take place in the roots, preventing ion movement to the aerial part of the plant. This mechanism occurs in some glycophytes and in most of the halophytes (salt-tolerant). The development of saline vesicle glands in the epidermis can facilitate the excretion of salts, preventing salt accumulation in different organs such as the leaves. Another example of exclusion mechanism is the salts accumulation in the old leaves causing death and fall of these organs.

The halophyte Plantago coronopus L. may behave as a typical $\mathrm{Na}^{+}$includer that may be used as osmoticum to lower the osmotic potential necessary for the maintenance of leaf turgor [13]. This could 
indicate that these solutes were responsible for the osmotic adjustment described above. The cost of intracellular ion compartmentation is relatively small compared with the energy needed to synthesise organic solutes for osmotic adjustment [10]. However, the maintenance of leaf turgor is a controversial issue. Horie et al. [174] considered that salt accumulation in the leaf apoplast could be responsible for the death of leaves in plants exposed to salinity.

\section{Photosynthesis and Chlorophyll Fluorescence}

Salt stress affects photosynthesis both in the short and long term. In the short term, salinity can affect photosynthesis by stomatal limitations, leading to a decrease in carbon assimilation [18]. This effect can produce rapid growth cessation, even after just a few hours of salt exposure [17].

In the long term, salt stress can also affect the photosynthetic process due to salt accumulation in young leaves [9] and decreases in chlorophyll and carotenoid concentrations even in halophyte plants $[14,175,176]$. The photosynthesis rate $\left(\mathrm{P}_{\mathrm{N}}\right)$ can drop due to stomatal closure (gs), and/or other non-stomatal limitations, like the disturbance of the photosynthetic electron chain and/or the inhibition of the Calvin Cycle enzymes, such as Rubisco, phosphoenol pyruvate carboxylase (PECP), ribulose-5-phosphate kinase, glyceraldehyde-3-phosphate dehydrogenase or fructose-1,6-bisphosphatase $[18,177]$. A drop in gs can prevent excess water loss by transpiration, whereas proper regulation of the photosynthetic process can minimise the generation of ROS in PS II $\left({ }^{1} \mathrm{O}_{2}\right)$ and in the reducing side of the PSI $\left(\mathrm{O}_{2} \cdot{ }^{-}\right.$and $\left.\mathrm{H}_{2} \mathrm{O}_{2}\right)$ [178].

It is known that salt-tolerant species show increased or unchanged chlorophyll content under salinity conditions, whereas chlorophyll levels decrease in salt-sensitive species, suggesting that this parameter can be considered a biochemical marker of salt tolerance in plants [14,27].

In myrtle plants treated with different $\mathrm{NaCl}$ levels (from 4 to $8 \mathrm{dS} \cdot \mathrm{m}^{-1}$ ) for 15 days, the leaf chlorophyll levels remained unchanged, whereas in eugenia plants subjected to the same treatment, the chlorophyll levels increased [28,29].

Analysing chlorophyll fluorescence is an easy and popular technique used in plant physiology studies that can provide interesting information about the state of the PSII [179]. Under saline conditions, a general decrease in photochemical quenching parameters $\left(\mathrm{F}_{\mathrm{v}} / \mathrm{F}_{\mathrm{m}}, \mathrm{Y}(\mathrm{II}), \mathrm{qP}\right)$ and in the electron transport rate (ETR) takes place, but increases in non-photochemical quenching parameters [qN, NPQ, Y(NPQ)] have also been reported [28,29,180-182] (Figure 2). The response to $\mathrm{NaCl}$ stress is correlated with decreases in PSII efficiency and increases in non-photochemical quenching parameters as a mechanism to safely dissipate excess energy. Salt stress was found to reduce ETR in a salt-sensitive rice cultivar, whereas only a slight reduction in ETR occurred in a salt-tolerant cultivar. However, the effect of $\mathrm{NaCl}$ stress on non-photochemical quenching parameters was somewhat different, since qN increased more substantially in the salt-tolerant cultivar than in the salt-sensitive cultivar [180]. In salt-sensitive plants, salt stress, besides reducing photochemical-quenching parameters and ETR, also reduces non-photochemical quenching parameters [181,183].

Decreases in photochemical and non-photochemical quenching parameters that occur in plants subjected to salt stress depend on the plant species and the severity of the stress. For example, in the salt-sensitive Cucumis sativus L. plants, whose growth was severely inhibited when subjected to $75 \mathrm{mM}$ $\mathrm{NaCl}$ for up to 7 days [183]. After 15 days of salt treatment, eugenia plants subjected to 8 and $12 \mathrm{dS} \mathrm{m}^{-1}$ $\mathrm{NaCl}$ responded to the imposed stress with decreases in $\mathrm{qP}$ and $\mathrm{Y}(\mathrm{II})$ and a concomitant increase in the non-photochemical quenching parameters, a mechanism for safely dissipating excess light energy and minimising ROS generation [179]. At 30 days of stress, the increase in $\mathrm{qP}$ and $\mathrm{Y}$ (II) and the decrease in the non-photochemical quenching parameters observed in salt-treated plants paralleled the response observed in the gas exchange parameters, indicating an adaptive response to the imposed stress conditions (Figure 2). The recovery period was detected by plants as a new challenge, as evidenced by an alteration in the fluorescence parameters, especially in plants previously treated with 8 or $12 \mathrm{dS} \mathrm{m}^{-1} \mathrm{NaCl}$ [29]. The observed decrease in qP as well as the drop in non-photochemical quenching parameters in this period suggested the generation of ROS in the chloroplasts as well as photooxidative 
damage [184], a response similar to that in $\mathrm{NaCl}$-sensitive plants. In myrtle plants, no correlation between $P_{N}$ and fluorescence parameters was observed at 15 days of salt stress. At 30 days of stress, however, the drop in $\mathrm{P}_{\mathrm{N}}$ paralleled a decline in qP and $\mathrm{Y}(\mathrm{II})$ and increases in non-photochemical parameters, as a safe mechanism for dissipating excess light energy [29] (Figure 2). After the post-stress period, the partial recovery in $\mathrm{P}_{\mathrm{N}}$ observed in myrtle plants previously treated with $4 \mathrm{dS} \mathrm{m}^{-1} \mathrm{NaCl}$ correlated with increases in $\mathrm{qP}$ and $\mathrm{Y}(\mathrm{II})$, whereas in plants previously subjected to $8 \mathrm{dS} \mathrm{m}^{-1} \mathrm{NaCl}$, both $\mathrm{qN}$ and $\mathrm{Y}(\mathrm{NPQ})$ dropped [28], reflecting a decrease in the safe dissipation of excess energy that could induce photo-oxidative damage in the photosynthetic apparatus [179]. Long-term $\mathrm{NaCl}$ treatment (75-150 mM) also decreased $\mathrm{Y}(\mathrm{II})$ and $\mathrm{Y}(\mathrm{NPQ})$ in Lawsonia inermis L. plants [94].

\section{E. myrtifolia}
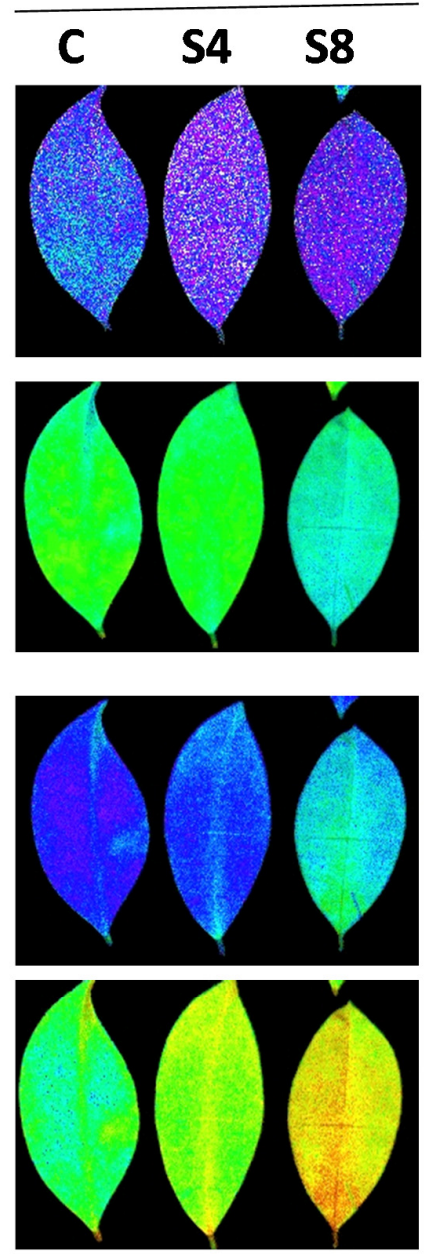

\section{M. communis}
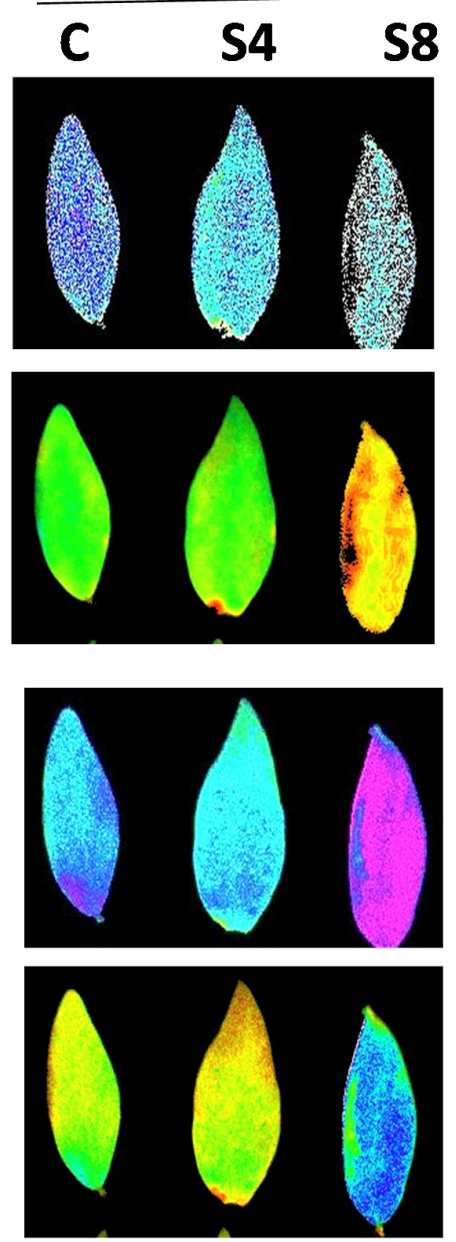

NPQ

0

Figure 2. Chlorophyll fluorescence parameters in leaves of E. myrtifolia and M. communis plants at 30 days of $\mathrm{NaCl}$ stress. Images of the coefficient of photochemical quenching (qP), the effective PSII quantum yield [Y(II)], the non-photochemical quenching coefficient (qN) and non-photochemical quenching (NPQ). C, control plants; $\mathrm{S} 4,4 \mathrm{dS} \mathrm{m}^{-1} ; \mathrm{S} 8,8 \mathrm{dS} \mathrm{m}^{-1}$. In the presence of salt stress, the photochemical quenching parameters increased in Eugenia plants, whereas myrtle plants showed increased non-photochemical quenching parameters, as a safe mechanism for dissipating excess light energy and minimising reactive oxygen species (ROS) generation. Partially reproduced from $[28,29]$. 


\section{Mechanisms for the Protection of the Photosynthetic Machinery}

The photosynthetic apparatus might be damaged even under moderate light if the excess light cannot be properly dissipated, favouring the generation of ROS that can damage the photosynthetic machinery [185]. This situation may be more severe under salinity conditions. One of the mechanisms involved in the safe dissipation of excess excitation energy in PSII is the so-called xanthophyll cycle. Under stress conditions, the carotenoid violaxanthin is converted to zeaxanthin by the enzyme violaxanthin de-epoxidase [186]. This cycle has a role in the dissipation of excess excitation energy in the PSII antenna as heat by a process termed non-photochemical quenching (NPQ) [186]. In addition, zeaxanthin has been reported to play an important role as an antioxidant. Accordingly, the accumulation of zeaxanthin in transgenic tomatoes was found to alleviate salt-induced photoinhibition and photo-oxidation due to the antioxidant role of zeaxanthin in the scavenging of singlet oxygen and/or free radicals in the tilakoid membranes [186]. Furthermore, Huang et al. [187] reported the important role of ascorbate in the protection of the photosynthetic machinery. Under salt stress, the Arabidopsis vtc-1 mutant showed a more significant decrease in $\mathrm{P}_{\mathrm{N}}$ and in all the chlorophyll fluorescence parameters than did the wild-type plants, indicating that the decrease in $P_{N}$ was due to ascorbate deficiency. Accordingly, ascorbate plays a central role in the protection of the chloroplast under salt stress conditions since it acts as a ROS scavenger and is a cofactor of violaxanthin de-epoxidase, which is involved in excess light energy dissipation in the xanthophyll cycle [185].

Photorespiration can act as a sink for excess reducing power, thereby preventing the over-reduction of the photosynthetic electron chain [188]. In addition, the photorespiratory pathway serves to convert phosphoglycolate (2PG) to 3-phosphoglycerate (3PGA), which can be metabolised to either regenerate RuBP or to make complex sugars and other carbon-based organic metabolites [189]. These effects can be even more important considering that different stress conditions can increase photorespiratory rates [190]. Drought and salinity, for example, trigger a decrease in stomatal conductance, thus decreasing the $\mathrm{CO}_{2}: \mathrm{O}_{2}$ ratio and increasing photorespiration [190]. Under salinity conditions, the photorespiratory pathway can prevent photo-oxidative damage by continuously recycling $\mathrm{CO}_{2}$ for the chloroplast from the decarboxylation of glycine in the mitochondria. In addition, glycerate, produced inside the peroxisome, can be imported into the chloroplast and enter the Calvin cycle. These mechanisms keep the Calvin cycle working and prevent ROS generation in the electron transport chain, providing substrates for the chloroplast and decreasing the risk of photoinhibition under environmental stress conditions.

The stimulation of glycolate oxidase activity by salinity in pea leaf peroxisomes from salt-tolerant plants suggests that photorespiration can act as a molecular mechanism in NaCl-tolerance [191]. In C3 plants, both $\mathrm{CO}_{2}$ fixation and photorespiration are the major sinks of electrons from PSII (4 electrons are required for $\mathrm{CO}_{2}$ or $\mathrm{O}_{2}$ reacting with Rubisco) [192].

In some salt-tolerant plants, increases in catalase activity have been recorded after an $\mathrm{NaCl}$ challenge, such as those described in tomato plants and myrtle, suggesting increased photorespiratory activity $[25,26,28]$. CAT has been found predominantly in leaf peroxisomes, where it chiefly functions to remove $\mathrm{H}_{2} \mathrm{O}_{2}$ formed in photorespiration or in the $\beta$-oxidation of fatty acids in the glyoxysomes [193]. The increase in CAT activity in salt-tolerant plants may suggest an involvement of photorespiration in the $\mathrm{NaCl}$ stress response. A correlation between CAT activity and photosynthesis has been described, since an increase in CAT reduces the photorespiratory loss of $\mathrm{CO}_{2}$ [194].

Another protective mechanism for the photosynthetic machinery is the water-water cycle [178]. This cycle can be defined as the photoreduction of molecular oxygen to water in PSI by the electrons generated in PSII from water [178]. In this cycle, half of the electrons generated in PSII are used for the photoreduction of dioxygen to superoxide in PSI, and the other half are used for the regeneration of ascorbate (for more details of this cycle please consult the revision by Asada [178]). The primary function of the water-water cycle is the protection of the chloroplast components from the ROS. For example, different enzymes (Calvin cycle, photorespiration, chloroplast APX and SOD, etc.) can be inhibited by ROS [178]. In addition, the water-water cycle allows linear electron flow for 
ATP production that could be used in the photorespiratory pathway, which also dissipates excess photon energy.

\section{Biochemical Adaptations}

\subsection{Antioxidative Metabolism}

It is well known that salinity induces oxidative stress in plants at the subcellular level $[21-23,25,26,195]$. Different works have reported that salt stress induces an accumulation of superoxide radicals $\left(\mathrm{O}_{2}\right)$ and hydrogen peroxide $\left(\mathrm{H}_{2} \mathrm{O}_{2}\right)$ in different cell compartments, including chloroplasts, mitochondria and apoplastic space, which correlates with increases in some oxidative stress parameters, such as lipid peroxidation and protein oxidation $[7,21-23,25,196,197]$. In contrast, in leaf or root peroxisomes from salt-treated plants, no important changes in $\mathrm{O}_{2}{ }^{-}$or $\mathrm{H}_{2} \mathrm{O}_{2}$ concentration have been reported $[25,26,191]$, although lipid peroxidation levels have increased in some cases. In pea leaf peroxisomes, $\mathrm{H}_{2} \mathrm{O}_{2}$ concentrations were even statistically lower in the presence of $\mathrm{NaCl}$ than in control plants, in spite of the inhibition of catalase (an $\mathrm{H}_{2} \mathrm{O}_{2}$-scavenger enzyme) and an increase in the $\mathrm{H}_{2} \mathrm{O}_{2}$-producing enzyme glycollate oxidase [190].

Different papers have shown that the response of the antioxidative defences of the salt-tolerant species is somewhat different to that of salt-sensitive species. For example, some authors have described a coordinated up-regulation of the antioxidative machinery as one of the mechanisms involved in the salt tolerance response $[23,25,195,196,198]$. Other authors have correlated salt tolerance with higher constitutive levels of certain antioxidant enzymes [24,199-201]. In contrast, the antioxidant defences in salt-sensitive species show an unchanged response or even a decrease, and these species display lower constitutive antioxidant enzyme levels than salt-tolerant species [21,22,24-26,201] (Table 2). In different salt-tolerant species, increases in the antioxidant defences have been reported. For example, in salt-tolerant pea cultivars (cv. Granada and cv. Puget) increases have been observed in the antioxidant defences in chloroplasts and mitochondria $[21,22,196]$. In the wild salt-tolerant related tomato species Lycopersicon pennellii, salt-induced oxidative stress was alleviated by a selective up-regulation of a set of antioxidant enzymes at the subcellular level. Increases in SOD and the ASC-GSH cycle components took place in the chloroplasts, mitochondria and peroxisomes from salt-treated (100 mM NaCl) Lycopersicon pennellii plants, whereas in the cultivated tomato (Solanum lycopersicom), which is sensitive to $100 \mathrm{mM} \mathrm{NaCl}$, a drop occurred in most of these antioxidant defences $[25,26,197]$ (Table 3). It has been also described that NADPH regeneration systems, especially in roots, contribute to maintaining the redox state, and this seems to be essential in the biochemical mechanisms of plant defence against oxidative stress situations [202].

Furthermore, the salinity tolerance response of myrtle and eugenia plants to $\mathrm{NaCl}(44-88 \mathrm{mM})$ has been found to parallel increases in certain antioxidant defences, including MDHAR and catalase in the case of myrtle and MDHAR, GR, SOD and GSH concentrations in the case of eugenia [28,29].

In general, salt stress affects ascorbate and glutathione levels much more in sensitive plants than in tolerant plants. $\mathrm{NaCl}$ stress produced a $50 \%$ reduction in the total ascorbate pool in soluble fractions in an $\mathrm{NaCl}$-sensitive pea genotype after 15 days of stress. This reduction was due to the loss of both the oxidized (DHA) and the reduced (ASC) forms. In an NaCl-tolerant genotype, salt stress also reduced SC and DHA levels but less so than the sensitive plants. Furthermore, no effect was observed on the ASC/DHA ratio. In contrast, less difference was observed in the glutathione concentrations. Even so, the reduced form (GSH) concentration decreased more in the $\mathrm{NaCl}$-sensitive plants than in the $\mathrm{NaCl}$-tolerant plants [195]. 
Table 2. Effect of salt stress on the activity of antioxidant enzymes in different plant models from salt-tolerant species.

\begin{tabular}{|c|c|c|c|c|c|}
\hline Plant Specie & $\mathrm{NaCl}$ Treatment & Enzyme & Response & Cell Compartment & References \\
\hline Pisum sativum cv. Granada & $70 \mathrm{mM}$ & Mn-SOD & increase & Leaf mitochondria & [21] \\
\hline Pisum sativum cv. Puget ${ }^{\mathrm{a}}$ & $90 \mathrm{mM}$ & APX, MDHAR, DHAR & increase & Leaf mitochondria & [196] \\
\hline \multirow[t]{4}{*}{ Lycopersicon pennellii } & $100 \mathrm{mM}$ & $\begin{array}{l}\text { Mn-SOD, APX, MDHAR, } \\
\text { DHAR, GPX }\end{array}$ & increase & Leaf mitochondria & [25] \\
\hline & & GR & decrease & Leaf mitochondria & [25] \\
\hline & & Mn-SOD, APX & increase & Root Mitochondria & [26] \\
\hline & & DHAR & decrease & Root Mitochondria & \\
\hline Pisum sativum cv. Puget & $90 \mathrm{mM}$ & APX, DHAR, GR & increase & Chloroplasts & [196] \\
\hline Pisum sativum cv. Granada & $70 \mathrm{mM}$ & $\mathrm{Cu}, \mathrm{Zn}-\mathrm{SOD}, \mathrm{APX}$ & increase & Chloroplasts & {$[22]$} \\
\hline \multirow[t]{2}{*}{ Triticum durum Desf. cv. Ofanto } & $50 \mathrm{mM}$ & stAPX, tAPX & increase & Chloroplasts & [203] \\
\hline & & stMDHAR, stDHAR & decrease & Chloroplasts & \\
\hline Suaeda salsa & $400 \mathrm{mM}$ & $\mathrm{tCu}-\mathrm{Zn}-\mathrm{SOD}$ & increase & Chloroplasts & [204] \\
\hline Pisum sativum cv. Puget & $70-110 \mathrm{mM}$ & $\begin{array}{l}\text { tFe-SOD, sFe-SOD, tCuZn-SOD, } \\
\text { sCuZn-SOD, sAPX, tAPX }\end{array}$ & increase & Chloroplasts & [205] \\
\hline Pisum sativum cv. Granada & $70 \mathrm{mM}$ & CAT & decrease & Leaf peroxisomes & [191] \\
\hline \multirow[t]{2}{*}{ Lycopersicon pennellii } & $100 \mathrm{mM}$ & SOD, APX, MDHAR, CAT & increase & Leaf peroxisomes & [25] \\
\hline & $100 \mathrm{mM}$ & Mn-SOD, APX, MDHAR, CAT & increase & Root peroxisomes & [26] \\
\hline Pisum sativum cv. Puget & $90 \mathrm{mM}$ & SOD & increase & Leaf apoplast & [23] \\
\hline Triticum aestivam L. cv Gerek-79 & $250-500 \mathrm{mM}$ & POX, SOD & increase & Leaf apoplast & [206] \\
\hline Populus euphratica Oliv. & $100-250 \mathrm{mM}$ & SOD & Increase & Xylem sap & [207] \\
\hline Brassica oleracea L. & $80 \mathrm{mM}$ & POX & Increase & Xylem sap & [208] \\
\hline Pisum sativum cv. Granada & $70 \mathrm{mM}$ & APX, MDHAR, DHAR, GR & increase & Soluble fractions & [195] \\
\hline Lotus japonica & $150 \mathrm{mM}$ & $\mathrm{Cu}, \mathrm{Zn}-\mathrm{SOSD}, \mathrm{DHAR}$ & increase & Leaf and root crude extract & [198] \\
\hline Oriza sativa cv. Pokkali & $100 \mathrm{mM}$ & CAT & decrease & Leaf crude extract & [181] \\
\hline Oriza sativa cv. 651, cv. 632 & 6 and $12 \mathrm{dS} / \mathrm{m}$ & SOD, GR, APX & increase & Leaf crude extract & [180] \\
\hline
\end{tabular}

${ }^{\mathrm{a}} \mathrm{cv}$ Puget behaves as salt-tolerant at $\mathrm{NaCl}$ concentrations up to $90 \mathrm{mM}$. 
Table 3. Effect of salt stress on the activity of antioxidant enzymes in different cell compartments from salt-sensitive species.

\begin{tabular}{|c|c|c|c|c|c|}
\hline Plant Specie & $\mathrm{NaCl}$ Treatment & Enzyme & Response & Cell Compartment & References \\
\hline Pisum sativum cv. Challis & $70 \mathrm{mM}$ & Mn-SOD & decrease & Leaf mitochondria & {$[21]$} \\
\hline Pisum sativum cv. Puget ${ }^{a}$ & $110 \mathrm{mM}$ & $\begin{array}{c}\text { Mn-SOD, APX, MDHAR, } \\
\text { DHAR }\end{array}$ & $\begin{array}{l}\text { increase } \\
\text { decrease }\end{array}$ & Leaf mitochondria & {$[196]$} \\
\hline Lycopersicon esculentum $\mathrm{L}$. & $100 \mathrm{mM}$ & Mn-SOD, MDHAR, GR & decrease & Leaf mitochondria & [25] \\
\hline & & Mn-SOD, MDHAR & decrease & Root Mitochondria & {$[26]$} \\
\hline Pisum sativum cv. Puget & $110 \mathrm{mM}$ & $\begin{array}{c}\text { Fe-SOD, Cu,Zn-SOD, APX, DHAR } \\
\text { MDHAR }\end{array}$ & $\begin{array}{l}\text { increase } \\
\text { decrease }\end{array}$ & Chloroplasts & [196] \\
\hline Triticum durum Desf. cv. Adamello & $50 \mathrm{mM}$ & $\begin{array}{c}\text { tAPX } \\
\text { stAPX, stDHAR }\end{array}$ & $\begin{array}{l}\text { increase } \\
\text { decrease }\end{array}$ & $\begin{array}{l}\text { Chloroplasts } \\
\text { Chloroplasts }\end{array}$ & [203] \\
\hline Pisum sativum cv. Puget & 70-110 mM & $\begin{array}{c}\text { Fe-SOD, CuZn-SOD, APX, DHAR } \\
\text { MDHAR }\end{array}$ & $\begin{array}{l}\text { increase } \\
\text { decrease }\end{array}$ & Chloroplasts & [205] \\
\hline Pisum sativum cv. Challis & $70 \mathrm{mM}$ & CAT & decrease & Leaf peroxisomes & [191] \\
\hline Lycopersicon esculentum L. & $100 \mathrm{mM}$ & SOD, APX, MDHAR, DHAR & decrease & Root peroxisomes & {$[26]$} \\
\hline Pisum sativum cv. Lincoln & $90 \mathrm{mM}$ & SOD & decrease & Leaf apoplast & {$[23]$} \\
\hline Triticum aestivam L. cv Bezostaya & $250-500 \mathrm{mM}$ & $\begin{array}{l}\text { SOD } \\
\text { POX }\end{array}$ & $\begin{array}{l}\text { increase } \\
\text { decrease }\end{array}$ & Leaf apoplast & {$[206]$} \\
\hline Populus popularis cv. $35-44$ & $100-250 \mathrm{mM}$ & SOD, APX, GR & Increase & Xylem sap & [207] \\
\hline Pisum sativum cv. Challis & $70 \mathrm{mM}$ & $\begin{array}{l}\text { CuZn-SOD I } \\
\text { DHAR }\end{array}$ & $\begin{array}{l}\text { decrease } \\
\text { increase }\end{array}$ & Soluble fractions & [195] \\
\hline Arabidopsis thaliana & $100 \mathrm{mM}$ & $\mathrm{Cu}, \mathrm{Zn}-\mathrm{SOD}, \mathrm{CAT}$ & increase & Leaf crude extract & [202] \\
\hline Cucumis sativus & $75 \mathrm{mM}$ & $\begin{array}{c}\text { APX, DHAR, GR } \\
\text { MDHAR }\end{array}$ & $\begin{array}{l}\text { decrease } \\
\text { increase }\end{array}$ & Chloroplast & [183] \\
\hline Vitis vinifera & $100 \mathrm{mM}$ & $\begin{array}{c}\text { APX } \\
\text { SOD, POX }\end{array}$ & $\begin{array}{l}\text { decrease } \\
\text { increase }\end{array}$ & In vitro plants & [182] \\
\hline Oryza sativa cv. IR-29 & $\begin{array}{c}100 \mathrm{mM} \\
6,12 \mathrm{dS} / \mathrm{m}\end{array}$ & $\begin{array}{c}\text { APX, CAT } \\
\text { SOD, APX, GR }\end{array}$ & $\begin{array}{l}\text { increase } \\
\text { decrease }\end{array}$ & $\begin{array}{l}\text { Leaf crude extract } \\
\text { Leaf crude extract }\end{array}$ & $\begin{array}{l}{[181]} \\
{[180]}\end{array}$ \\
\hline
\end{tabular}

${ }^{a} \mathrm{cv}$ Puget behaves as salt-sensitive at $\mathrm{NaCl}$ concentrations over $110 \mathrm{mM}$. 
Both ASC and GSH were detected in the leaf apoplastic space of two pea cultivars with different levels of $\mathrm{NaCl}$ sensitivity. ASC and GSH levels did not change in either cultivar in response to $\mathrm{NaCl}$, although the redox state of the ascorbate and glutathione pools decreased progressively with the severity of the stress ( 0 to $90 \mathrm{mM} \mathrm{NaCl}$ ). Nevertheless, all these changes were, again, less pronounced in the resistant cultivar, which furthermore had higher constitutive levels of ASC and GSH in its apoplastic space than the sensitive cultivar [23]. The effect of $\mathrm{NaCl}$ on the ASC and GSH levels was also analysed in the leaf symplast of both pea cultivars. The data showed that ASC levels began to fall in the susceptible cultivar in the presence of $50 \mathrm{mM} \mathrm{NaCl}$, whereas in the resistant cultivar this response occurred in the presence of higher $\mathrm{NaCl}$ levels $(90 \mathrm{mM})$ [23]. Regarding symplastic $\mathrm{GSH}$, the response was similar in both cultivars, but GSSG accumulation was only significant in the susceptible cultivar when exposed to $90 \mathrm{mM} \mathrm{NaCl}$ [23].

In grapevine plantlets, $100 \mathrm{mM} \mathrm{NaCl}$ did not affect ASC levels, but an accumulation of DHA occurred. Regarding glutathione pool, salt treatment reduced the GSH concentration but no effect was observed on GSSG levels. In both cases, a reduction in the redox state of ascorbate and glutathione occurred [182].

$\mathrm{NaCl}$ resulted in a decrease in the ascorbate and glutathione levels in chloroplasts from cucumber seedlings, and both forms of the two antioxidants were affected, especially the oxidized forms (DHA and GSSG). In this case, the GSH levels were much more affected than the ascorbate levels [183].

$\mathrm{NaCl}$ stress $(100 \mathrm{mM})$ produced a decline in the ASC content in leaves of the salt-sensitive rice cultivar IR-29, but no effect was recorded in the roots of this rice cultivar or in the leaves or roots of an NaCl-tolerant rice cultivar (Pokkali) [181].

\subsection{ROS and RNS Generation}

Chloroplasts and mitochondria are important sources of ROS in plants subjected to salt stress. As a consequence of photosynthesis and Calvin cycle impairment, the over-reduction of the electron chain along with the lack of regeneration of the final electron acceptor in PSI $\left(\mathrm{NADP}^{+}\right)$favour electron transfer from ferredoxin to oxygen to form $\mathrm{O}_{2} \cdot{ }^{-}$(Mehler Reaction), which is disproportionated to $\mathrm{H}_{2} \mathrm{O}_{2}$ and $\mathrm{O}_{2}$ by SOD [178]. In addition, singlet oxygen $\left({ }^{1} \mathrm{O}_{2}\right)$ generation is increased when the photoinhibition of PSII occurs in illuminated chloroplasts [209]. Under salt stress conditions, an increase in $\mathrm{H}_{2} \mathrm{O}_{2}$ content was reported in the chloroplasts of two pea cultivars, although this increase was much higher in the salt-sensitive cultivar than in the salt-tolerant one [22]. In another salt-tolerant pea cultivar (cv. Puget), the chloroplast $\mathrm{H}_{2} \mathrm{O}_{2}$ content increased up to 3.5-fold when plants were treated with $110 \mathrm{mM}$ $\mathrm{NaCl}[196]$.

In plant mitochondria, two different sites of superoxide generation have been described which are located at the flavoprotein NADH dehydrogenase and at the ubiquinone-cytochrome $b$ segments [210]. In sub-mitochondrial particles from pea plants, $\mathrm{NaCl}$ treatments increased $\mathrm{NADH}$-dependent $\mathrm{O}_{2}{ }^{-}$generation in an $\mathrm{NaCl}$-tolerant cultivar and in an $\mathrm{NaCl}$-sensitive cultivar. Nevertheless, the succinate-dependent $\mathrm{O}_{2}{ }^{-}$generation was much higher in the $\mathrm{NaCl}$-sensitive cultivar than in the resistant cultivar [21]. However, in these conditions, the Mn-SOD and $\mathrm{Cu}, \mathrm{Zn}-\mathrm{SOD}$ I isoenzymes only decreased in the mitochondria from the $\mathrm{NaCl}$-sensitive cultivar, whereas a significant increase in Mn-SOD took place in the mitochondria from the tolerant cultivar. The ability of the mitochondria from the salt-sensitive cultivar to scavenge $\mathrm{O}_{2}{ }^{-}$was therefore reduced under conditions with higher $\mathrm{O}_{2}{ }^{-}$ generation. However, despite the increase in the $\mathrm{O}_{2}{ }^{-}$rate generation in pea mitochondria under salt stress conditions, no change in the endogenous $\mathrm{H}_{2} \mathrm{O}_{2}$ concentration was detected. A similar response was reported in mitochondria from the salt-tolerant pea cultivar Puget by the effect of $70 \mathrm{mM} \mathrm{NaCl}$. The unchanged mitochondrial $\mathrm{H}_{2} \mathrm{O}_{2}$ levels under salinity conditions could be explained by the fact that the membranes are permeable to $\mathrm{H}_{2} \mathrm{O}_{2}$, and $\mathrm{H}_{2} \mathrm{O}_{2}$ diffusion can be increased by $\mathrm{NaCl}$ stress [211]. However, 2- and 3-fold increases in mitochondrial $\mathrm{H}_{2} \mathrm{O}_{2}$ have been observed in the presence of 90 and $110 \mathrm{mM} \mathrm{NaCl}$, respectively [196]. The decrease in mitochondrial antioxidant defences has been correlated with higher rates of lipid peroxidation and protein oxidation [21,196]. 
Peroxisomes also generate ROS as a result of their metabolism. In pea leaf peroxisomes, there are at least two sites of $\mathrm{O}_{2} \cdot{ }^{-}$generation: the reaction of the enzyme xanthine oxidase in the matrix and an $\mathrm{NAD}(\mathrm{P}) \mathrm{H}$-dependent $\mathrm{O}_{2}{ }^{-}$generating enzyme in the peroxisomal membrane [212]. In addition, $\mathrm{H}_{2} \mathrm{O}_{2}$ is produced at a high rate in peroxisomes by the action of different $\mathrm{H}_{2} \mathrm{O}_{2}$-producing flavin oxidases, with the photorespiratory glycolate oxydase enzyme being one of the most important $\mathrm{H}_{2} \mathrm{O}_{2}$ generators [213]. In peroxisomal membranes from pea leaves, neither the NADH-induced generation of $\mathrm{O}_{2} \cdot{ }^{-}$nor the lipid peroxidation of membranes was found to be altered by salt stress, and results were similar in $\mathrm{NaCl}$-tolerant and $\mathrm{NaCl}$-sensitive pea plants [191]. In contrast, $\mathrm{NaCl}$ produced a decrease in the endogenous $\mathrm{H}_{2} \mathrm{O}_{2}$ concentration in leaf peroxisomes in both pea cultivars [191]. These authors suggested that $\mathrm{H}_{2} \mathrm{O}_{2}$ could react non-enzymatically with some peroxisomal metabolite whose concentration could be induced by salt stress [191]. This response has also been observed in root peroxisomes from tomato plants [26]. In this case, the authors attributed the decrease in the $\mathrm{H}_{2} \mathrm{O}_{2}$ levels in root peroxisomes, at least partially, to the fact that there were greater increases in APX and CAT activities than in SOD activities. In other words, the $\mathrm{H}_{2} \mathrm{O}_{2}$ detoxification rate is higher than the $\mathrm{H}_{2} \mathrm{O}_{2}$ production rate under salinity [26]. Alternatively, peroxisomal $\mathrm{H}_{2} \mathrm{O}_{2}$ could be potentially dangerous by leaking out, reaching the cytosol and inducing oxidative stress in this cell compartment [191]. $\mathrm{H}_{2} \mathrm{O}_{2}$ is also generated by the spontaneous and/or enzymatic dismutation of $\mathrm{O}_{2} \cdot{ }^{-}$radicals in all cell compartments [178,214].

The effect of salt stress on ROS accumulation (mainly $\mathrm{H}_{2} \mathrm{O}_{2}$ ) can be also analysed by colorimetric methods in different plant tissues. By using the xylenol orange method [215] and Barba-Espín et al. [97] observed that $70 \mathrm{mM} \mathrm{NaCl}$ did not affect leaf $\mathrm{H}_{2} \mathrm{O}_{2}$ in pea leaves, but in the combined treatment using $\mathrm{NaCl}$ plus salicylic acid ( 50 or $100 \mu \mathrm{M}$ ), a $35 \%$ increase in leaf $\mathrm{H}_{2} \mathrm{O}_{2}$ was observed. Using the same methodology, García de la Garma et al. [216] analysed the effect of $\mathrm{NaCl}$ stress on the $\mathrm{H}_{2} \mathrm{O}_{2}$ levels in tobacco BY-2 cells at different growth phases. These authors also observed an accumulation of $\mathrm{H}_{2} \mathrm{O}_{2}$ in all the growth phases analysed. Furthermore, by using confocal laser microscopy, they found ROS accumulation in the cytoplasm and mitochondria. The effect of salinity on ROS levels $\left(\mathrm{O}_{2}{ }^{-}\right.$ and $\mathrm{H}_{2} \mathrm{O}_{2}$ ) was also monitored in the xylem sap in two poplar cultivars with different levels of salt sensitivity [217]. After 18 days of treatment $(250 \mathrm{mM} \mathrm{NaCl})$ these authors only observed significant $\mathrm{O}_{2}{ }^{-}$and $\mathrm{H}_{2} \mathrm{O}_{2}$ accumulation in the $\mathrm{NaCl}$-sensitive plants. $\mathrm{NaCl}$ increased $\mathrm{H}_{2} \mathrm{O}_{2}$ in the apoplast in a concentration-dependent manner. Nevertheless, the apoplastic $\mathrm{H}_{2} \mathrm{O}_{2}$ levels were nearly 4-5-times higher in an $\mathrm{NaCl}$-sensitive cultivar than in an $\mathrm{NaCl}$-tolerant cultivar when plants were exposed to 70 or $90 \mathrm{mM} \mathrm{NaCl}$ [23].

Salt stress also produces increased $\mathrm{O}_{2} \cdot{ }^{-}$generation in the chloroplast, as observed in cucumber seedling growth in the presence of $75 \mathrm{mM} \mathrm{NaCl}$, which also correlated with higher lipid peroxidation results [183].

Salt stress was also found to increase the $\mathrm{H}_{2} \mathrm{O}_{2}$ levels in different plum lines overexpressing cytosolic $\mathrm{Cu}, \mathrm{Zn}$-SOD and/or APX. In this study, all transgenic plum lines had lower levels of $\mathrm{H}_{2} \mathrm{O}_{2}$ than non-transformed wild-type plants under salt exposure (100 mM) [207].

ROS accumulation under salt stress can be also monitored by the staining of plant tissues with diaminebenzydine (DAB, to locate $\mathrm{H}_{2} \mathrm{O}_{2}$ ) or with Nitroblue tetrazolium (NBT, to locate $\mathrm{O}_{2} \cdot{ }^{-}$). In pea leaves, salt stress $(90 \mathrm{mM} \mathrm{NaCl})$ was found to produce an accumulation of $\mathrm{H}_{2} \mathrm{O}_{2}$ and $\mathrm{O}_{2} \cdot{ }^{-}$that was more evident in a salt-sensitive cultivar (cv. Lincoln) than in a relatively salt-tolerant cultivar (cv. Puget) [23]. In grapevine plantlets, $100 \mathrm{mM} \mathrm{NaCl}$ also produced $\mathrm{ROS}$ accumulation in leaves. In this case, a different pattern of $\mathrm{H}_{2} \mathrm{O}_{2}$ and $\mathrm{O}_{2}{ }^{-}$accumulation was observed: the $\mathrm{H}_{2} \mathrm{O}_{2}$ staining appeared as small spots on the leaf surface, whereas the $\mathrm{O}_{2}{ }^{-}$staining was observed in the veins [182].

Besides ROS, nitric oxide (NO) is also involved in the response of plants to salinity. Different works have reported that pre-treatment with a NO-donor (such as SNP) can improve the response of plants to NaCl-induced damage [218,219]. For example, exogenous NO application has been found to protect soybean plants and sunflower cotyledons from $\mathrm{NaCl}$ stress. In soybean plants, $\mathrm{NO}$ increased RWC, chlorophyll and ABA levels, and plants displayed better stomatal control [218]. In addition, NO 
can act as a regulator of glutathione metabolism, modulating the activity of GSH-dependent enzymes such as GST, GR, and GSH contents [218-220].

$\mathrm{NaCl}$ increased $\mathrm{NO}$ generation in tomato roots, but produced a decrease in nitrosoglutathione (GSNO), probably due to the strong drop in GSH under saline conditions [220]. GSNO is considered a NO reservoir in plants, and the balance between both molecules may act as a regulation mechanism in the response to salt stress, at least in roots [220]. It seems that under salt stress conditions, plant peroxisomes, in addition to generating ROS, are the main source of NO production [221]. These same authors also demonstrated that peroxisomes are required for $\mathrm{NO}$ accumulation in the cytosol, thereby participating in the production of peroxynitrite $\left(\mathrm{ONOO}^{-}\right)$, resulting in a nitrosative stress, moniroted by an increase in protein Tyr nitration in salt-stressed plants [221,222].

\subsection{Effect of Biostimulants in the Salt-Stress Response}

Different studies have demonstrated that the addition of pre-treatment with various molecules can improve or enhance the plant response to salt stress. For example, the exogenous application of $\mathrm{H}_{2} \mathrm{O}_{2}$ can induce salt tolerance in different plant species, including rice, wheat and maize [223].

Recently, Kaur and Bhatla [219] found that exogenous melatonin can improve salinity effects in sunflower cotyledons by modulating GSH metabolism or by increasing the activity of $\mathrm{H}_{2} \mathrm{O}_{2}$-scavenging enzymes (APX, CAT, POX), improving the photosynthetic rate and increasing the $\mathrm{K}^{+} / \mathrm{Na}^{+}$ratio in Malus hupehensis Rehd [224].

The effects of SA treatments on the response of plants to salinity have also been studied. However, the results obtained vary depending on the plant species, growth conditions, and the SA and stress application rates. To give an example, foliar SA application significantly improved the growth of $\mathrm{NaCl}$-treated tomato plants. This alleviation of $\mathrm{NaCl}$ toxicity by SA was related to a decrease in $\mathrm{Na}$ concentrations, an increase in $\mathrm{K}$ and $\mathrm{Mg}$ concentrations in the shoots and roots, and an increase in the antioxidant mechanism [225]. SA application was also found to partially protect pistachio seedlings against salt stress injuries by improving different physiological parameters such as RWC, chlorophyll content, chlorophyll fluorescence and the photosynthetic rate [226]. However, other works have found that SA treatments negatively affect the response of plants to $\mathrm{NaCl}$, and that this response correlated with an imbalance in the antioxidant metabolism [97]. Borsani et al. [227] found that SA increased oxidative damage during both $\mathrm{NaCl}$ and osmotic stress and was critical in Arabidopsis seedling mortality under these conditions.

The protective role of polyamines (PAs) against salt stress has been also examined. For example, PA treatment improved the response of mung bean seedlings to salt stress by enhancing the levels of glutathione and ascorbate in addition to the activity of different antioxidant enzymes, including DHAR, GR, CAT and GPX [228]. The possible involvement of PAs in salt stress adaptation has also been investigated in grapevine (Vitis vinifera L.) plantlets. Treatment of plantlets with methylglyoxal bis(guanylhydrazone) (MGBG), a S-adenosylmethionine decarboxylase (SAMDC) inhibitor, enhanced the salt stress effects [182]. Salt and/or MGBG treatments also triggered an increase in lipid peroxidation and ROS accumulation but decreased APX activity and reduced glutathione [182]. These authors suggested that maintaining PA biosynthesis through enhanced SAMDC activity in grapevine leaf tissues under salt stress conditions could contribute to enhanced ROS scavenging activity and to protection of the photosynthetic apparatus from oxidative damage.

\section{Conclusions}

Salinity is one of the most significant environmental challenges limiting plant productivity. In the short term, salt stress is first perceived by the root system, inducing osmotic stress and causing reduced water availability. In the long term, salt stress induces ion toxicity due to nutrient imbalances in the cytosol.

A proper root system can ensure water and nutrient uptake in saline conditions and improve plant resistance to saline conditions. In general, salt stress produces a decrease in the aerial part of the plant, 
partially associated with leaf abscission mediated by ethylene production. This decrease in growth can be considered a mechanism to minimise water loss by transpiration. Moreover, an increased root to shoot ratio has been described under salinity. A bigger root proportion under salt stress can favour the retention of toxic ions, which can be an important mechanism of plant resistance/survival under saline conditions (Figure 3).

The accumulation and compartmentalisation of toxic ions and/or compatible solutes is therefore one of the mechanisms involved in salt-tolerance. Toxic ion accumulation can be an energetically cheap and positive way for plants to obtain osmotic regulation, but only if they are able to compartmentalise the ions in the vacuole. Among the organic osmolytes, Pro and GB are the most important as efficient compatible solutes. In addition to acting as an osmoprotectant, Pro has been reported to have antioxidant properties, but it can also act as a molecular chaperone to protect the structure of biological macromolecules. In general, salt-tolerant species accumulate Pro after a salt-stress challenge. GB, on the other hand, can act as an osmolyte to protect PSII during salinity (Figure 3).

It is known that prolonged salt stress may cause changes in leaf anatomy. In general, tolerant species respond by increasing leaf thickness. Anatomical modifications in leaves also include an increase in palisade parenchyma and intercellular spaces and a decrease in spongy parenchyma, serving to facilitate $\mathrm{CO}_{2}$ diffusion in a situation of reduced stomatal aperture.

Damage to the chloroplast is an important aspect of the effect of salinization on leaf cells (Figure 3). The main salt-induced changes in the chloroplast ultrastructure include changes in starch content, disarranged thylakoids and grana and increased numbers of plastoglobuli. In tolerant plants, decreases observed in starch content could suggest that the starch is used for different physiological processes to cope with the salt stress challenge.

In salt-tolerant plants, plant growth is less affected. Salt exclusion and salt compartmentalisation in vacuoles and the accumulation of osmolytes are important mechanisms for salt tolerance. PN and gs are also affected in salt-tolerant species, and an increase in the ratio $\mathrm{P}_{\mathrm{N}} / \mathrm{gs}$ (WUEi) indicates better photosynthetic performance. In general, salt-tolerant species display greater increases in the induction and/or constitutive levels of certain antioxidant defences than salt-sensitive plants. In general, tolerant species respond by increasing leaf thickness and succulence. Anatomical modifications in leaves also include an increase in palisade parenchyma and intercellular spaces and a decrease in spongy parenchyma, serving to facilitate $\mathrm{CO}_{2}$ diffusion in a situation of reduced stomatal aperture. At the root zone, the accumulation of toxic ions also provokes a decrease in the root osmotic potential. In general, increases in root density takes place in tolerant species that favour the retention of toxic ions in roots, limiting the accumulation of these ions in the canopy. Finally, it is well known that both the presence of arbuscular mycorrhizal fungi (AMF) and salt-tolerant rootstocks produce a synergic effect that can alleviate the negative effects of salt stress.

Salt stress affects photosynthesis both in the short and long term (Figure 3). In the short term, salinity can affect photosynthesis by stomatal limitations (the stomatal factor), leading to a decrease in carbon assimilation. In the long term, salt stress can also affect the photosynthetic process due to salt accumulation in young leaves, leading to the loss of photosynthetic pigments and the inhibition of Calvin cycle enzymes (non-stomatal factors). As a mechanism to protect the photosynthesis process, tolerant species respond by maintaining or increasing their chlorophyll content.

In general, salt-sensitive plants show a drop in photochemical quenching parameters but an increase in non-photochemical quenching parameters. However, and depending on the plant species and the severity of the stress, a decrease in both photochemical and non-photochemical quenching parameters can also take place (Figure 3). 


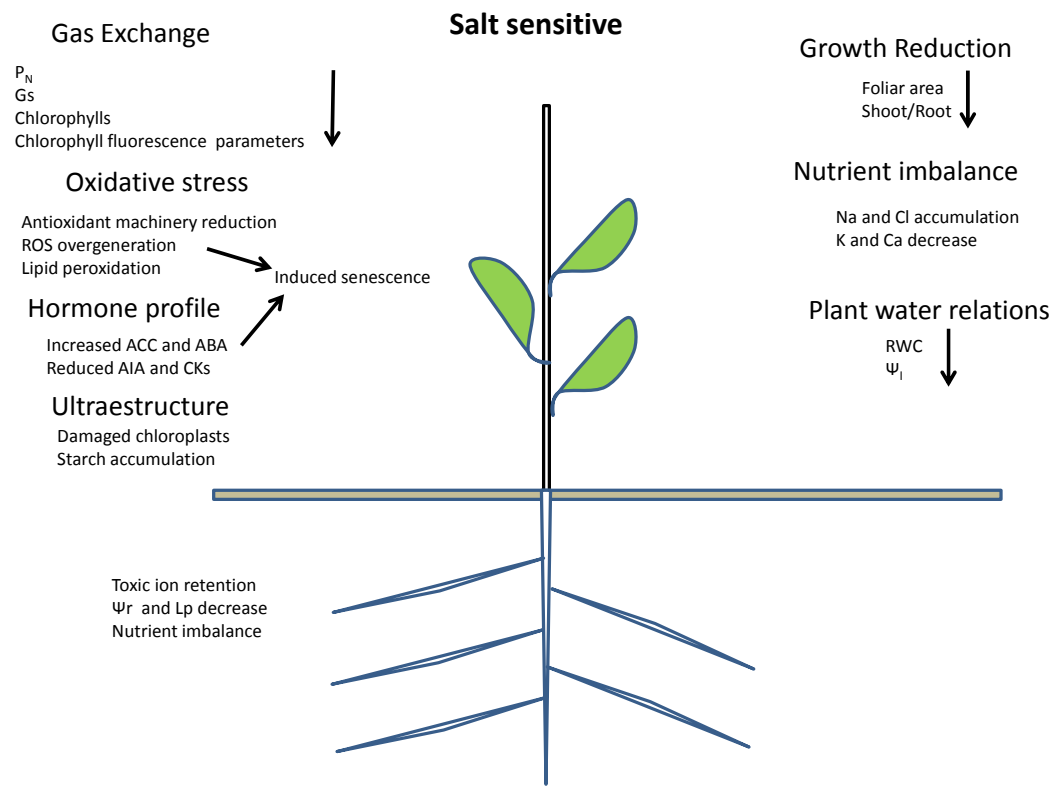

(A)

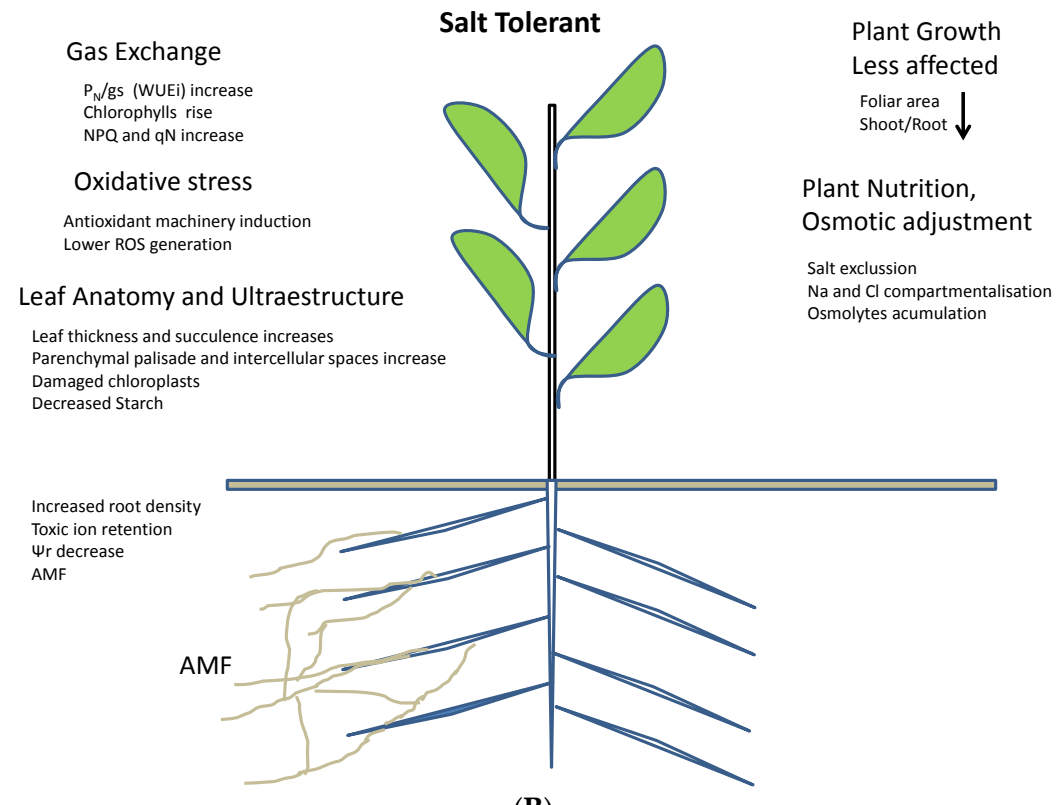

(B)

Figure 3. Schema showing the effect of salinity on salt-sensitive (A) and salt-tolerant (B) plants. Salt stress produces an important decrease in plant growth in salt-sensitive plants, especially in relation to the aerial part. The accumulation of phytotoxic ions in leaves results in a nutrient imbalance particularly reflected in decreases in $\mathrm{K}^{+}$and $\mathrm{Ca}^{2+}$. Salinity disturbs a plant's water relations, leading to lower leaf relative water content (RWC) and leaf water potential $\left(\psi_{1}\right)$. Salt stress affects the photosynthesis rate $\left(\mathrm{P}_{\mathrm{N}}\right)$ by stomatal and non-stomatal limitations. In addition, decreases in chlorophyll content and in chlorophyll fluorescence parameters occurs in parallel. In addition, oxidative stress at the subcellular level takes place by the effect of salt stress. In salt-stressed plants the synthesis of ethylene and abscisic acid (ABA) increases, but a decrease occurs in indol-3-acetic acid (IAA) and cytokinin (CK) that favours the progression of senescence in salinized leaves. Damage to the chloroplast is an important aspect of the effect of salinization, accompanied by starch accumulation. The accumulation of salts in the root zone causes a decrease in osmotic potential, root water potential $\left(\psi_{\mathrm{r}}\right)$ and the root hydraulic conductivity (Lp), diminishing the water available to the root zone and provoking a nutrient imbalance in roots. 
Salinity induces oxidative stress at the subcellular level (Figure 3), particularly in the chloroplast, which can affect the photosynthesis process. In this regards, plants have developed mechanisms for protecting their photosynthetic machinery. One of the mechanisms involved in the safe dissipation of excess excitation energy in PSII is the so-called xanthophyll cycle, whose function is to dissipate excess excitation energy in the PSII antenna as heat by a process termed non-photochemical quenching (NPQ). Photorespiration is another protective mechanism that can act as a sink for excess reducing power, thereby preventing the over-reduction of the photosynthetic electron chain. Moreover, the so-called water-water cycle is also a protective mechanism for the photosynthetic machinery. The primary function of this pathway is the protection of the chloroplast components from the ROS, but it also acts as a mechanism for dissipating excess photon energy.

As mentioned, it is well known that salinity induces oxidative stress in plants at the subcellular level, and those chloroplasts and mitochondria are important sources of ROS in plants subjected to salt stress. Some authors have described a coordinated up-regulation of the antioxidative machinery as one of the mechanisms involved in the salt tolerance response, whereas other authors have correlated salt tolerance with higher constitutive levels of certain antioxidant enzymes. In contrast, salt-sensitive species show an unchanged response or even a decrease in antioxidant defences, and they display lower constitutive antioxidant enzyme levels than salt-tolerant species (Figure 3).

Acknowledgments: PDV thanks CSIC and the Spanish Ministry of Economy and Competitiveness for their 'Ramon \& Cajal' research contract, co-financed by FEDER funds. We thank Spanish Ministry of Economy and Competitiveness (Project AGL2014-52563-R) and Seneca Foundation of Murcia (Project 19903/GERM/15).

Author Contributions: JAHC and JRAM projected the design of the review. JAHC, PDV and ABV wrote all the information related with Photosynthesis and Chlorophyll Fluorescence, Biochemical Adaptations: JRAM wrote all the information related with Morphological Adaptations of Plants to Salinity and Leaf Anatomy and Ultrastructure Changes in Leaves under Salinity. MJSB and MFO wrote all the information related with Water Relations, Gas Exchange and Osmotic Regulation and Related Salt Tolerance Mechanisms. JAHC and JRAM made all the Figures and Tables. JRAM ordered all the references.

Conflicts of Interest: We have not any conflict of interest.

\section{References}

1. Ashraf, M.; Harris, J.C. Potential biochemical indicators of salinity tolerance in plants. Plant Sci. 2004, 166, 3-16. [CrossRef]

2. Hussain, K.; Majeed, A.; Nawaz, K.; Khizar, H.B.; Nisar, M.F. Effect of different levels of salinity on growth and ion contents of black seeds (Nigella sativa L.). Curr. Res. J. Biol. Sci. 2009, 1, 135-138.

3. Colla, G.; Rouphael, Y.; Leonardi, C.; Bie, Z. Role of grafting in vegetable crops grown under saline conditions. Sci. Hort. 2010, 127, 147-155. [CrossRef]

4. De Pascale, S.; Dalla-Costa, L.; Vallone, S.; Barbieri, G.; Maggio, A. Increasing water use effieciency in vegetable crop production: From plant to irrigation system efficiency. HortTechnology 2011, 21, 301-308.

5. Munns, R.; Gilliham, M. Salinity tolerance of crops-What is the cost? New Phytol. 2015, 208, 668-673. [CrossRef] [PubMed]

6. Acosta-Motos, J.R.; Ortuño, M.F.; Álvarez, S.; López-Climent, M.F.; Gómez-Cadenas, A.; Sánchez-Blanco, M.J. Changes in growth, physiological parameters and the hormonal status of Myrtus communis L. plants irrigated with water with different chemical compositions. J. Plant Physiol. 2016, 191, 12-21. [CrossRef] [PubMed]

7. Acosta-Motos, J.R.; Hernández, J.A.; Álvarez, S.; Barba-Espín, G.; Sánchez-Blanco, M.J. Long-term resistance mechanisms and irrigation critical threshold showed by Eugenia myrtifolia plants in response to saline reclaimed water and relief capacity. Plant Physiol. Biochem. 2017, 111, 244-256. [CrossRef] [PubMed]

8. Cirillo, C.; Rouphael, Y.; Caputo, R.; Raimondi, G.; Sifola, M.I.; De Pascale, S. Efects of high salinity and the exogenous of an osmolyte on growth, phosynthesis and mineral composition in two ornamental shrubs. J. Hortic. Sci. Biotechnol. 2016, 91, 14-22. [CrossRef]

9. Munns, R.; Tester, M. Mechanisms of salinity tolerance. Ann. Rev. Plant Biol. 2008, 59, 651-681. [CrossRef] [PubMed]

10. Munns, R. Comparative physiology of salt and water stress. Plant Cell Environ. 2002, 25, 239-250. [CrossRef] [PubMed] 
11. Tang, X.; Mu, X.; Shao, H.; Wang, H.; Brestic, M. Global plant-responding mechanisms to salt stress: Physiological and molecular levels and implications in biotechnology. Crit. Rev. Biotechnol. 2015, 35, 425-437. [CrossRef] [PubMed]

12. Munns, R. Genes and salt tolerance: Bringing them together. Plant Physiol. 2005, 167, 645-663. [CrossRef] [PubMed]

13. Koyro, H.W. Effect of salinity of growth, photosynthesis, water relations and solute composition of the potential cash crop halophyte Plantago coronopus (L.). Environ. Exp. Bot. 2006, 56, 136-146. [CrossRef]

14. Stepien, P.; Johnson, G.N. Contrasting responses of photosynthesis to salt stress in the glycophyte Arabidopsis and the halophyte Thellungiella: Role of the plastid terminal oxidase as an alternative electron sink. Plant Physiol. 2009, 149, 1154-1165. [CrossRef] [PubMed]

15. Larcher, W. Physiological Plant Ecology, 4th ed.; Springer-Verlag: Heidelberg/Berlin, Germany; New York, NY, USA, 2003.

16. Munns, R.; Termaat, A. Whole plant response to salinity. Aust. J. Plant Physiol. 1986, 13, 143-160. [CrossRef]

17. Hernández, J.A.; Almansa, M.S. Short-term effects of salt stress on antioxidant systems and leaf water relations of pea plants. Physiol. Plant. 2002, 115, 251-257. [CrossRef] [PubMed]

18. Parida, A.K.; Das, A.B. Salt tolerance and salinity effects on plants: A review. Ecotoxicol. Environ. Saf. 2005, 60, 324-349. [CrossRef] [PubMed]

19. Flowers, T.J.; Colmer, T.D. Plant salt tolerance: Adaptations in halophytes. Ann. Bot. 2015, 115, 327-331. [CrossRef] [PubMed]

20. Marschner, H. Mineral Nutrition of Higher Plants, 2nd ed.; Academic Press: London, UK, 1995.

21. Hernández, J.A.; Corpas, F.J.; Gómez, M.; del Río, L.A.; Sevilla, F. Salt induced oxidative stress mediated by activated oxygen species in pea leaf mitochondria. Physiol. Plant. 1993, 89, 103-110. [CrossRef]

22. Hernández, J.A.; Olmos, E.; Corpas, F.J.; Sevilla, F.; del Río, L.A. Salt-induced oxidative stress in chloroplast of pea plants. Plant Sci. 1995, 105, 151-167. [CrossRef]

23. Hernández, J.A.; Ferrer, M.A.; Jiménez, A.; Ros-Barceló, A.; Sevilla, F. Antioxidant systems and $\mathrm{O}_{2} / \mathrm{H}_{2} \mathrm{O}_{2}$ production in the apoplast of Pisum sativum L. leaves: Its relation with $\mathrm{NaCl}$-induced necrotic lesions in minor veins. Plant Physiol. 2001, 127, 817-831. [CrossRef] [PubMed]

24. Hernández, J.A.; Aguilar, A.; Portillo, B.; López-Gómez, E.; Mataix-Beneyto, J.; García-Legaz, M.F. The effect of calcium on the antioxidant enzymes from salt-treated loquat and anger plants. Funct. Plant Biol. 2003, 30, 1127-1137. [CrossRef]

25. Mittova, V.; Tal, M.; Volokita, M.; Guy, M. Up-regulation of the leaf mitochondrial and peroxisomal antioxidative systems in response to salt-induced oxidative stress in the wild salt-tolerant tomato species Lycopersicon pennellii. Plant Cell Environ. 2003, 26, 845-856. [CrossRef] [PubMed]

26. Mittova, V.; Guy, M.; Tal, M.; Volokita, M. Salinity up-regulates the antioxidative system in root mitocondria and peroxisomes of the wild salt-tolerant tomato species Lycopersicon pennellii. J. Exp. Bot. 2004, 399, 1105-1113. [CrossRef] [PubMed]

27. Ashraf, M.; Harris, P.J.C. Photosynthesis under stressful environments: An overview. Photosynthetica 2013, 51, 163-190. [CrossRef]

28. Acosta-Motos, J.R.; Díaz-Vivancos, P.; Álvarez, S.; Fernández-García, N.; Sánchez-Blanco, M.J.; Hernández, J.A. NaCl-induced physiological and biochemical adaptative mechanism in the ornamental Myrtus cummunis L. plants. J. Plant Physiol. 2015, 183, 41-51. [CrossRef] [PubMed]

29. Acosta-Motos, J.R.; Díaz-Vivancos, P.; Álvarez, S.; Fernández-García, N.; Sánchez-Blanco, M.J.; Hernández, J.A. Physiological and biochemical mechanisms of the ornamental Eugenia myrtifolia L. plants for coping with $\mathrm{NaCl}$ stress and recovery. Planta 2015, 242, 829-846. [CrossRef] [PubMed]

30. Munns, R. A leaf elongation assay detects an unknown growth inhibitor in xylem sap from wheat and barley. Aust. J. Plant Physiol. 1992, 19, 127-135. [CrossRef]

31. Azza Mazher, A.M.; Fatma El-Quesni, E.M.; Farahat, M.M. Responses of ornamental plants and woody trees to salinity. World J. Agric. Sci. 2007, 3, 386-395.

32. Passioura, J.B. Water Transport in and to Roots. Ann. Rev. Plant Physiol. Plant Mol. Biol. 1988, 39, $245-265$. [CrossRef]

33. Vamerali, T.; Saccomani, M.; Bona, S.; Mosca, G.; Guarise, M.; Ganis, A. A comparison of root characteristics in relation to nutrient and water stress in two maize hybrids. Plant Soil 2003, 255, 157-167. [CrossRef] 
34. Franco, J.A.; Bañón, S.; Vicente, M.J.; Miralles, J.; Martínez-Sánchez, J.J. Root development in horticultural plants grown under abiotic stress conditions-A review. J. Hortic. Sci. Biotechnol. 2011, 86, 543-556. [CrossRef]

35. Ma, S.C.; Li, F.M.; Xu, B.C.; Huang, Z.B. Effect of lowering the root/shoot ratio by pruning roots on water use efficiency and grain yield of winter wheat. Field Crops Res. 2010, 115, 158-164. [CrossRef]

36. Steudle, E. Water uptake by roots: Effects of water deficit. J. Exp. Bot. 2000, 51, 1531-1542. [CrossRef] [PubMed]

37. Ranathunge, K.; Shao, S.; Qutob, D.; Gijzen, M.; Peterson, C.A.; Bernards, M.A. Properties of the soybean seed coat cuticle change during development. Planta 2010, 231, 1171-1188. [CrossRef] [PubMed]

38. Shannon, M.C.; Grieve, C.M.; Francois, L.E. Whole-plant response to salinity. In Plant-Environment Interactions; Wilkinson, R.E., Ed.; Marcel Dekker, Inc.: New York, NY, USA, 1994; pp. 199-244.

39. Walker, R.R.; Sedgley, M.; Blesing, M.A.; Douglas, T.J. Anatomy, Ultrastructure and Assimilate Concentrations of Roots of Citrus Genotypes Differing in Ability for Salt Exclusion. J. Exp. Bot. 1984, 35, 1481-1494. [CrossRef]

40. Whiley, A.W.; Schaffer, B.; Wolstenholme, B.N. The Avocado. Botany, Production and Uses; CAB International: Wallingford, UK, 2002.

41. Bernstein, N.; Meiri, A.; Zilberstaine, M. Root Growth of Avocado is More Sensitive to Salinity than Shoot Growth. J. Am. Soc. Hortic. Sci. 2004, 129, 188-192.

42. Álvarez, S.; Sánchez-Blanco, M.J. Long-term effect of salinity on plant quality, water relations, photosynthetic parameters and ion distribution in Callistemon citrinus. Plant Biol. 2014, 16, 757-764. [CrossRef] [PubMed]

43. Álvarez, S.; Navarro, A.; Nicolás, E.; Sánchez-Blanco, M.J. Transpiration, photosynthetic responses, tissue water relations and dry mass partitioning in Callistemon plants during drought conditions. Sci. Hort. 2011, 129, 306-312. [CrossRef]

44. Álvarez, S.; Sánchez-Blanco, M.J. Changes in growth rate, root morphology and water use efficiency of potted Callistemon citrinus plants in response to different levels of water deficit. Sci. Hort. 2013, 156, 54-62. [CrossRef]

45. Gómez-Bellot, M.J.; Álvarez, S.; Castillo, M.; Bañón, S.; Ortuño, M.F.; Sánchez-Blanco, M.J. Water relations, nutrient content and developmental responses of Euonymus plants irrigated with water of different degrees of salinity and quality. J. Plant Res. 2013, 126, 567-576. [CrossRef] [PubMed]

46. Croser, C.; Renault, S.; Franklin, J.; Zwiazek, J. The effect of salinity on the emergence and seedling growth of Picea mariana, Picea glauca, and Pinus banksiana. Environ. Pollut. 2001, 115, 9-16. [CrossRef]

47. Cameron, R.W.F.; Harrison-Murray, R.S.; Atkinson, C.J.; Judd, H.L. Regulated deficit irrigation: A means to control growth in woody ornamentals. J. Hortic. Sci. Biotech. 2006, 81, 435-443. [CrossRef]

48. Franco, J.A.; Bañón, S.; Fernández, J.A.; Leskovar, D.I. Effect of nursery regimes and establishment irrigation on root development of Lotus creticus seedlings following transplanting. J. Hortic. Sci. Biotechnol. 2001, 76, 174-179. [CrossRef]

49. Franco, J.A.; Martínez-Sánchez, J.J.; Fernández, J.A.; Bañón, S. Selection and nursery production of ornamental plants for landscaping and xerogardening in semiarid environments. J. Hortic. Sci. Biotechnol. 2006, 81, 3-17. [CrossRef]

50. Rengasamy, P.; Olsson, K.A. Irrigation and sodicity. Aust. J. Soil Res. 1993, 31, 821-837. [CrossRef]

51. Jonathan, N.F.G.; Lehti-Shiu, M.D.; Ingram, P.A.; Deak, K.I.; Biesiada, T.; Malamy, J.E. Identification of quantitative trait loci that regulate Arabidopsis root system size and plasticity. Genetics 2006, 172, 485-498.

52. Zobel, R.W.; Kinraide, T.B.; Baligar, V.C. Fine root diameters can change in response to changes in nutrient concentrations. Plant Soil 2007, 297, 243-254. [CrossRef]

53. Navarro, J.M.; Gómez-Gómez, A.; Pérez-Pérez, J.G.; Botía, P. Effect of saline conditions on the maturation process of clementine Clemenules fruits on two different rootstocks. Span. J. Agric. Res. 2010, 8, 21-29. [CrossRef]

54. Penella, C.; Nebauer, S.G.; Quiñones, A.; San Bautista, A.; López-Galarza, S.; Calatayud, A. Some rootstocks improve pepper tolerance to mild salinity through ionic regulation. Plant Sci. 2015, 230, 12-22. [CrossRef] [PubMed] 
55. Penella, C.; Landi, M.; Guidi, L.; Nebauer, S.G.; Pellegrini, E.; San Bautista, A.; Remorini, D.; Nali, C.; López-Galarza, S.; Calatayud, A. Salt-tolerant rootstock increases yield of pepper under salinity through maintenance of photosynthetic performance and sinks strength. J. Plant Physiol. 2016, 193, 1-11. [CrossRef] [PubMed]

56. Navarro, J.M.; Pérez-Tornero, O.; Morte, A. Alleviation of salt stress in citrus seedlings inoculated with arbuscular mycorrhizal fungi depends on the rootstock salt tolerance. J. Plant Physiol. 2014, 171, 76-85. [CrossRef] [PubMed]

57. Gómez-Bellot, M.J.; Ortuño, M.F.; Nortes, P.A.; Vicente-Sánchez, J.; Martín, F.F.; Bañón, S.; Sánchez-Blanco, M.J. Protective effects of Glomus iranicum var. tenuihypharum on soil and Viburnum tinus plants irrigated with treated wastewater under field conditions. Mycorrhiza 2015, 25, 399-409.

58. Tudela, D.; Primo-Millo, E. 1-Aminocyclopropane-1-carboxylic acid transported from roots to shoots promotes leaf abscission in Cleopatra mandarin (Citrus reshni Hort. ex Tan.) seedlings rehydrated after water stress. Plant Physiol. 1992, 100, 131-137. [CrossRef] [PubMed]

59. Gómez-Cadenas, A.; Tadeo, F.R.; Talon, M.; Primo-Millo, E. Leaf abscission induced by ethylene in water stressed intact seedlings of Cleopatra mandarin requires previous abscisic acid accumulation in roots. Plant Physiol. 1996, 112, 401-408. [CrossRef] [PubMed]

60. Gómez-Cadenas, A.; Tadeo, F.R.; Primo-Millo, E.; Talon, M. Involvement of abscisic acid and ethylene in the response of citrus seedlings to salt shock. Physiol. Plant. 1998, 103, 475-484. [CrossRef]

61. Dodd, I.C. Root-to-shoot signalling: Assessing the roles of 'up' in the up and down world of long-distance signalling in planta. Plant Soil 2005, 74, 257-275.

62. Chrominski, A.; Bhat, R.B.; Weber, D.J.; Smith, B.N. Osmotic stress-dependent conversion of 1-aminocyclopropane-1-carboxylic acid (ACC) to ethylene in the halophyte, Allenrolfea occidentalis. Environ. Exp. Bot. 1988, 28, 171-174. [CrossRef]

63. Albacete, A.; Ghanem, M.E.; Martínez-Andújar, C.; Acosta, M.; Sánchez-Bravo, J.; Martínez, V.; Lutts, S.; Dodd, I.C.; Pérez-Alfocea, F. Hormonal changes in relation to biomass partitioning and shoot growth impairment in salinized tomato (Solanum lycopersicum L.) plants. J. Exp. Bot. 2008, 59, 4119-4131. [CrossRef] [PubMed]

64. Ghanem, M.E.; Albacete, A.; Martínez-Andújar, C.; Acosta, M.; Romero-Aranda, R.; Dodd, I.C.; Lutts, S.; Pérez-Alfocea, F. Hormonal changes during salinity-induced leaf senescence in tomato (Solanum lycopersicum L.). J. Exp. Bot. 2008, 59, 3039-3050. [CrossRef] [PubMed]

65. Savé, R.; Olivella, C.; Biel, C.; Adillón, J.; Rabella, R. Seasonal patterns of water relationships, photosynthetic pigments and morphology of Actinidia deliciosa plants of the Haywards and Tomouri cultivars. Agronomie 1994, 2, 121-126. [CrossRef]

66. Ruiz-Sánchez, M.C.; Domingo, R.; Torrecillas, A.; Pérez-Pastor, A. Water stress preconditioning to improve drought resistance in young apricot plants. Plant Sci. 2000, 156, 245-251. [CrossRef]

67. Colmer, T.D.; Muñiz, R.; Flowers, T.J. Improving salt tolerance of wheat and barley: Future prospects. Aust. J. Exp. Agric. 2005, 45, 1425-1443. [CrossRef]

68. Franco, J.A.; Fernández, J.A.; Bañón, S.; González, A. Relationship between the effects of salinity on seedling leaf area and fruit yield of six muskmelons cultivars. J. Hortic. Sci. 1997, 32, 642-647.

69. Rodríguez, P.; Torrecillas, A.; Morales, M.A.; Ortuño, M.F.; Sánchez-Blanco, M.J. Effects of NaCl salinity and water stress on growth and leaf water relations of Asteriscus maritimus plants. Environ. Exp. Bot. 2005, 53, 113-123. [CrossRef]

70. Hsiao, T.C.; Xu, L.K. Sensitivity of growth of roots versus leaves to water stress: Biophysical analysis and relation to water transport. J. Exp. Bot. 2000, 51, 1595-1616. [CrossRef] [PubMed]

71. Cassaniti, C.; Romano, D.; Flowers, T.J. The response of ornamental plants to saline irrigation water. In Irrigation Water Management, Pollution and Alternative Strategies; Garcia-Garizabal, I., Ed.; InTech Europe: Rijeka, Croatia, 2012; pp. 132-158.

72. Cassaniti, C.; Leonardi, C.; Flowers, T.J. The effects of sodium chloride ornamental shrubs. Sci. Hortic. 2009, 122, 586-593. [CrossRef]

73. Cramer, G.R. Sodium-calcium interactions under salinity stress. In Salinity: Environment-Plants-Molecules; Läuchli, A., Lüttge, U., Eds.; Kluwer: Dordrecht, The Netherlands, 2002; pp. 205-227.

74. Tattini, M.; Gucci, R.; Coradeschi, M.A.; Ponzio, C.; Everard, J.D. Growth, gas exchange and ion content in Olea europaea plants during salinity stress and subsequent relief. Physiol. Plant. 1995, 95, 203-210. [CrossRef] 
75. Zekri, M.; Parsons, L.R. Growth and root hydraulic conductivity of several citrus rootstocks under salt and polyethylene glycol stresses. Physiol. Plant. 1989, 77, 99-106. [CrossRef]

76. Morales, M.A.; Sánchez-Blanco, M.J.; Olmos, E.; Torrecillas, A.; Alarcón, J.J. Changes in the growth, leaf water relations and cell ultraestructure in Argyranthemum coronopifolium plants under saline conditions. J. Plant Physiol. 1998, 153, 174-180. [CrossRef]

77. Alarcón, J.J.; Morales, M.A.; Torrecillas, A.; Sánchez-Blanco, M.J. Growth, water relations and accumulation of organic and inorganic solutes in the halophyte Limonium latifolium cv. Avignon and its interspecific hybrid Limonium caspia x Limonium latifolium cv. Beltlaard during salt stress. J. Plant Physiol. 1999, 154, 795-801.

78. Hernández, J.A.; Campillo, A.; Jiménez, A.; Alarcon, J.J.; Sevilla, F. Response of antioxidant systems and leaf water relations to $\mathrm{NaCl}$ stress in pea plants. New Phytol. 1999, 141, 241-251. [CrossRef]

79. Chartzoulakis, K.; Loupassaki, M.; Bertaki, M.; Androulakis, I. Effects of $\mathrm{NaCl}$ salinity on growth, ion content and $\mathrm{CO}_{2}$ assimilation rate of six olive cultivars. Sci. Hort. 2002, 96, 235-247. [CrossRef]

80. Arbona, V.; Flors, V.; García-Agustín, P.; Jacas, J.; Gómez-Cadenas, A. Enzymatic and non-enzymatic antioxidant responses of Carrizo citrange, a salt-sensitive citrus rootstock, to different levels of salinity. Plant Cell Physiol. 2003, 44, 388-394. [CrossRef] [PubMed]

81. Torrecillas, A.; Rodríguez, P.; Sánchez-Blanco, M.J. Comparison of growth, leaf water relations and gas exchange of Cistus albidus and C. monspliensis plants irrigated with water of different $\mathrm{NaCl}$ salinity levels. Sci. Hort. 2003, 97, 353-368. [CrossRef]

82. Sánchez-Blanco, M.J.; Rodríguez, P.; Olmos, E.; Morales, M.A.; Torrecillas, A. Differences in the Effects of Simulated Sea Aerosol on Water Relations, Salt Content, and Leaf Ultrastructure of Rock-Rose Plants. J. Environ. Qual. 2004, 33, 1369-1375. [CrossRef] [PubMed]

83. Alarcón, J.J.; Morales, M.A.; Ferrández, T.; Sánchez-Blanco, M.J. Effects of water and salt stresses on growth, water relations and gas exchange in Rosmarinus officinalis. J. Hortic. Sci. Biotechnol. 2006, 81, 845-853. [CrossRef]

84. Niu, G.; Rodriguez, D.S. Relative Salt Tolerance of Five Herbaceous Perennials. HortScience 2006, 41, 1493-1497.

85. Navarro, A.; Bañón, S.; Olmos, E.; Sánchez-Blanco, M.J. Effects of sodium chloride on water potential components, hydraulic conductivity, gas exchange and leaf ultrastructure of Arbutus unedo plants. Plant Sci. 2007, 172, 473-480. [CrossRef]

86. López-Climent, M.F.; Arbona, V.; Pérez-Clemente, R.M.; Gómez-Cadenas, A. Relationship between salt tolerance and photosynthetic machinery performance in citrus. Environ. Exp. Bot. 2008, 62, 176-184. [CrossRef]

87. Bañón, S.; Miralles, J.; Franco, J.A.; Ochoa, R.; Sánchez-Blanco, M.J. Effects of diluted and pure treated wastewater on the growth, physiological status and visual quality of potted lantana and polygala plants. Sci. Hortic. 2011, 129, 869-876. [CrossRef]

88. Valdez-Aguilar, L.A.; Grieve, C.M.; Razak-Mahar, A.; McGiffen, M.; Merhaut, D.J. Growth and ion distribution is affected by irrigation with saline water in selected landscape species grown in two consecutive growing-seasons: Spring-summer and fall-winter. HortScience 2011, 46, 632-642.

89. Álvarez, S.; Gómez-Bellot, M.J.; Castillo, M.; Bañón, S.; Sánchez-Blanco, M.J. Osmotic and saline effect on growth, water relations, and ion uptake and translocation in Phlomis purpurea plants. Environ. Exp. Bot. 2012, 78, 138-145. [CrossRef]

90. Bañón, S.; Miralles, J.; Ochoa, J.; Sánchez-Blanco, M.J. The effect of salinity and high boron on growth, photosynthetic activity and mineral contents of two ornamental shrubs. Hort. Sci. 2012, 39, 188-194.

91. Sabra, A.; Daayf, F.; Renault, S. Differential physiological and biochemical responses of three Echinaceae species to salinity stress. Sci. Hort. 2012, 135, 23-31. [CrossRef]

92. Gónmez-Bellot, M.J.; Álvarez, S.; Bañón, S.; Ortuño, M.F.; Sánchez-Blanco, M.J. Physiological mechanisms involved in the recovery of euonymus and laurustinus subjected to saline waters. Agric. Water Manag. 2013, 128, 131-139.

93. Acosta-Motos, J.R.; Álvarez, S.; Barba-Espín, G.; Hernández, J.A.; Sánchez-Blanco, M.J. Salts and nutrients present in regenerated waters induce changes in water relations, antioxidative metabolism, ion accumulation and restricted ion uptake in Myrtus communis L. plants. Plant. Physiol. Biochem. 2014, 85, 41-50. [CrossRef] [PubMed] 
94. Fernández-García, N.; Olmos, E.; Bardisi, E.; García-De la Garma, J.; López-Berenguer, C.; Rubio-Asensio, J.S. Intrinsic water use efficiency controls the adaptation to high salinity in a semi-arid adapted plant, henna (Lawsonia inermis L.). J. Plant Physiol. 2014, 171, 64-75. [CrossRef] [PubMed]

95. Álvarez, S.; Sánchez-Blanco, M.J. Comparison of individual and combined effects of salinity and deficit irrigation on physiological, nutritional and ornamental aspects of tolerance in Callistemon laevis plants. J. Plant Physiol. 2015, 185, 65-74. [CrossRef] [PubMed]

96. Salachna, P.; Piechocki, R. Efects of sodium chloride on growth and mineral nutrition of purpletop vervain. J. Ecol. Eng. 2016, 17, 148-152. [CrossRef]

97. Barba-Espín, G.; Clemente-Moreno, M.J.; Álvarez, S.; García-Legaz, M.F.; Hernández, J.A.; Díaz-Vivancos, P. Salicylic acid negatively affects the response to salt stress in pea plants: Effects on PR1b and MAPK expression. Plant Biol. 2011, 13, 909-917. [CrossRef] [PubMed]

98. Van Genuchten, M.T. Research Report No. 120; U.S. Salinity Laboratory, USDA-ARS: Riverside, CA, USA, $1983 ;$ p. 50.

99. Zhen, A.; Bie, Z.; Huang, Y.; Liu, Z.; Li, Q. Effects of scion and rootstock genotypes on the anti-oxidant defense systems of grafted cucumber seedlings under $\mathrm{NaCl}$ stress. Soil Sci. Plant Nutr. 2010, 56, 263-271. [CrossRef]

100. Beadle, C.L. Growth analysis. In Photosynthesis and Production in a Changing Environment; Hall, D.O., Scurlock, J.M.O., Bolhar-Nordentrampf, H.R., Leegod, R.C., Long, S.P., Eds.; Chapman and Hall: London, UK, 1993; pp. 36-45.

101. Curtis, P.S.; Läuchli, A. The role of leaf area development and photosynthetic capacity in determining growth of kenaf under moderate salt stress. Aust. J. Plant Physiol. 1986, 18, 553-565. [CrossRef]

102. Cramer, G.R.; Epstein, E.; Läuchli, A. Effects of sodium, potassium and calcium on salt-stressed barley. 1. Growth analysis. Physiol. Plant. 1990, 80, 83-88. [CrossRef]

103. Olmos, E.; Sánchez-Blanco, M.J.; Ferrández, T.; Alarcón, J.J. Subcellular effects of drought stress in Rosmarinus officinalis. Plant Biol. 2007, 9, 77-84. [CrossRef] [PubMed]

104. Longstreth, D.J.; Nobel, P.S. Salinity effects of leaf anatomy. Plant Physiol. 1979, 63, 700-703. [CrossRef] [PubMed]

105. Romero-Aranda, R.; Moya, J.L.; Tadeo, F.R.; Legaz, F.; Primo-Millo, E.; Talon, M. Physiological and anatomical disturbances induced by chloride salts in sensitive and tolerant citrus: Beneficial and detrimental effects of cations. Plant Cell Environ. 1998, 21, 1243-1253. [CrossRef]

106. Franco-Navarro, J.D.; Brumós, J.; Rosales, M.A.; Cubero-Font, P.; Talón, M.; Colmenero-Flores, J.M. Chloride regulates leaf cell size and water relations in tobacco plants. J. Exp. Bot. 2016, 67, 873-891. [CrossRef] [PubMed]

107. Gómez-Bellot, M.J.; Nortes, P.A.; Ortuño, M.F.; Romero-Trigueros, C.; Fernández-García, N.; Sánchez-Blanco, M.J. Influence of arbuscular mycorrizal fungi and treated wastewater on water relations and leaf structure alterations of Viburnum tinus L. plants during both saline and recovery periods. J. Plant Physiol. 2015, 188, 96-105. [CrossRef] [PubMed]

108. Rouphael, Y.; De Micco, V.; Arena, C.; Raimondi, G.; Colla, G.; De Pascale, S. Effect of Ecklonia maxima seaweed extract on yield, mineral composition, gas exchange, and leaf anatomy of zucchini squash grown under saline conditions. J. Appl. Phycol. 2016. [CrossRef]

109. Flowers, T.J.; Duque, E.; Hajibagheri, M.A.; McGlonigle, T.P.; Yeo, A.R. The effect of salinity on leaf ultrastructure and net photosynthesis of two varieties of rice: Further evidence for a cellular component of salt-resistance. New Phytol. 1985, 100, 37-43. [CrossRef]

110. Austin, J.R.; Frost, E.; Vidi, P.A.; Kessler, F.; Staehelin, A. Plastoglobules are lipoprotein subcompartments of the chloroplast that are permanently coupled to thylakoid membranes and contain biosynthetic enzymes. Plant Cell 2006, 18, 1693-1703. [CrossRef] [PubMed]

111. Szabo-Nagi, A.; Galiba, G.; Erdei, L. Induction of soluble phosphatases under ionic and non-ionic osmotic stresses in wheat. J. Plant Physiol. 1992, 140, 629-633. [CrossRef]

112. Balibrea, M.E.; Dell'Amico, J.; Bolarín, M.C.; Pérez-Alfocea, F. Carbon partitioning and sucrose metabolism in tomato plants growing under salinity. Physiol. Plant. 2000, 110, 503-511. [CrossRef]

113. Passioura, J.B. Scaling up: The essence of effective agricultural research. Funct. Plant Biol. 2010, 37, 585-591. [CrossRef] 
114. Chavarria, G.; dos Santos, H.P. Plant water relations: Absorption, transport and control mechanisms. InTechOpen 2012, 5, 105-132.

115. Zhu, J.K. Plant salt tolerance. Trends Plant Sci. 2001, 6, 66-71. [CrossRef]

116. Ashraf, M. Some important physiological selection criteria for salt tolerance in plants. Flora 2004, 199, 361-376. [CrossRef]

117. Meloni, D.A.; Gulotta, M.R.; Martínez, C.A. Salinity tolerance in Schinopsis quebracho colorado: Seed germination, growth, ion relations and metabolic responses. J. Arid. Environ. 2008, 72, 1785-1792. [CrossRef]

118. Acosta-Motos, J.R.; Álvarez, S.; Hernández, J.A.; Sánchez-Blanco, M.J. Irrigation of Myrtus communis L. plants with reclaimed water: Morphological and physiological responses to different levels of salinity. J. Hortic. Sci. Biotechnol. 2014, 89, 487-494. [CrossRef]

119. Giri, B.; Kapoor, R.; Mukerji, K.G. Influence of arbuscular mycorrhizal fungi and salinity on growth, biomass, and mineral nutrition of Acacia auriculiformis. Biol. Fert. Soils 2003, 38, 170-175. [CrossRef]

120. Katerji, N.; van Hoorn, J.W.; Mastrorilli, M.; Hamdy, A. Crop sensitivity to salinity. In Non-Conventional Water Use: WASAMED Project; Hamdy, A., ElGamal, F., Lamaddalena, N., Bogliotti, C., Guelloubi, R., Eds.; CIHEAM/EU DG Research: Bari, Italy, 2005; pp. 43-51.

121. Bhatnagar-Mathur, P.; Devi, M.J.; Reddy, D.S.; Lavanya, M.; Vadez, V.; Serraj, R.; Yamaguchi-Shinozaki, K.; Sharma, K.K. Stress inducible expression of At DREB1A in transgenic peanut (Arachis hypogaea L.) increases transpiration efficiency under water limiting conditions. Plant Cell Rep. 2007, 26, 2071-2082. [CrossRef] [PubMed]

122. Alarcón, J.J.; Sánchez-Blanco, M.J.; Bolarín, M.C.; Torrecillas, A. Growth and osmotic adjustment of two tomato cultivars during and after saline stress. Plant Soil 1994, 166, 75-82. [CrossRef]

123. Navarro, A.; Bañón, S.; Conejero, W.; Sánchez-Blanco, M.J. Ornamental characters, ion accumulation and water status in Arbutus unedo seedlings irrigated with saline water and subsequent relief and transplanting. Environ. Exp. Bot. 2008, 62, 364-370. [CrossRef]

124. Kefu, Z.; Hai, F.; San, Z.; Jie, S. Study on the salt and drought tolerance of Suaeda salsa and Kalanchoe claigremontiana under iso-osmotic salt and water stress. Plant Sci. 2003, 165, 837-844. [CrossRef]

125. Hasegawa, P.M.; Bressan, R.A.; Zhu, J.K.; Bhnert, H.J. Plant cellular and molecular responses to high salinity. Ann. Rev. Plant Physiol. Plant Mol. Biol. 2000, 51, 463-499. [CrossRef] [PubMed]

126. Abdul-Jaleel, C.; Manivannan, P.; Sankar, B.; Kishorekumar, A.; Gopi, R.; Somasundaram, R.; Panneerselvam, R. Water deficit stress mitigation by calcium chloride in Catharanthus roseus: Effects on oxidative stress, proline metabolism and indole alkaloid accumulation. Colloids Surf. B. 2007, 60, 110-116. [CrossRef] [PubMed]

127. Kaldenhoff, R.; Ribas-Carbo, M.; Flexas, J.; Lovisolo, C.; Heckwolf, M.; Uehlein, N. Aquaporins and plant water balance. Plant Cell Environ. 2008, 31, 658-666. [CrossRef] [PubMed]

128. Jacoby, B. Mechanisms envolved in salt tolerante by plants. In Handbook of Plant and Crop Stress; Pessarakli, M., Ed.; Marcel Dekker: New York, NY, USA, 1994; pp. 97-123.

129. Kriedmann, P.E.; Barrs, H.D. Citrus orchards. In Water Deficits and Plant Growth; Kozlowski, T.T., Ed.; VI Academic Press: New York, NY, USA, 1981; pp. 325-417.

130. Stiller, V.; Lafitte, H.R.; Sperry, J.S. Hydraulic Properties of Rice and the Response of Gas Exchange to Water Stress. Plant Physiol. 2003, 132, 1698-1706. [CrossRef] [PubMed]

131. Tyree, M.T. Hydraulic limits on tree performance: Transpiration, carbon gain and growth of trees. Trees Struct. Funct. 2003, 17, 95-100.

132. Brodribb, T.J. Xylem hydraulic physiology: The functional backbone of terrestrial plant productivity. Plant Sci. 2009, 177, 245-251. [CrossRef]

133. Lo Gullo, M.A.; Trifilò, P.; Raimondo, F. Hydraulic characteristics and water relations in pigment-less mutant shoots of an orange tree. Tree Physiol. 2007, 27, 209-217. [CrossRef] [PubMed]

134. Sánchez-Blanco, M.J.; Rodríguez, P.; Morales, M.A.; Ortuño, M.F.; Torrecillas, A. Comparative growth and water relations of Cistus albidus and Cistus monspeliensis plants during water deficit conditions and recovery. Plant Sci. 2002, 162, 107-113. [CrossRef]

135. Slama, I.; Ghnaya, T.; Savouré, A.; Abdelly, C. Combined effects of long-term salinity and soil drying on growth, water relations, nutrient status and proline accumulation of Sesuvium portulacastrum. C. R. Biol. 2008, 331, 442-451. [CrossRef] [PubMed] 
136. Pérez-Pérez, J.G.; Robles, J.M.; García-Sánchez, F.; Botía, P. Comparison of deficit and saline irrigation strategies to confront water restriction in lemon trees grown in semi-arid regions. Agric. Water Manag. 2016, 164, 46-57. [CrossRef]

137. Kerstiens, G.; Tych, W.; Robinson, M.F.; Mansfield, T.A. Sodium-related partial stomatal closure and salt tolerance of Aster tripolium. New Phytol. 2002, 153, 509-515. [CrossRef]

138. Veselov, D.S.; Sharipova, G.V.; Veselov, S.U.; Kudoyarova, G.R. The Effects of NaCl Treatment on Water Relations, Growth, and ABA Content in Barley Cultivars Differing in Drought Tolerance. J. Plant Growth Regul. 2008, 27, 380. [CrossRef]

139. Vysotskaya, L.; Hedley, P.E.; Sharipova, G.; Veselov, D.; Kudoyarova, G.; Morris, J.; Jones, H.G. Effect of salinity on water relations of wild barley plants differing in salt tolerance. AoB Plants 2010. [CrossRef] [PubMed]

140. Cochard, H.; Coll, L.; Roux, X.L.; Ameglio, T. Unraveling the effects of plant hydraulics on stomatal closure during water stress in walnut. Plant Phys. 2002, 128, 282-290. [CrossRef]

141. Meinzer, F.C. Co-ordination of vapour and liquid phase water transport properties in plants. Plant Cell Environ. 2002, 25, 265-274. [CrossRef] [PubMed]

142. Bunce, J.A. How do leaf hydraulics limit stomatal conductance at high water vapour pressure deficits? Plant Cell Environ. 2006, 29, 1644-1650. [CrossRef] [PubMed]

143. Davies, W.J.; Kudoyarova, G.; Hartung, W. Long-distance ABA signaling and its relation to other signaling pathways in the detection of soil drying and the mediation of the plant's response to drought. J. Plant Growth Regul. 2005, 24, 285-295. [CrossRef]

144. Dodd, I.C.; Puértolas, J.; Huber, K.; Pérez-Pérez, J.G.; Wright, H.R.; Blackwell, M.S.A. The importance of soil drying and re-wetting in crop phytohormonal and nutritional responses to deficit irrigation. J. Exp. Bot. 2015, 66, 2239-2252. [CrossRef] [PubMed]

145. Mulholland, B.J.; Taylor, I.B.; Jackson, A.C.; Thompson, A.J. Can ABA mediate responses of salinity stressed tomato? Environ. Exp. Bot. 2003, 50, 17-28. [CrossRef]

146. Fricke, W.; Akhiyarova, G.; Veselov, D.; Kudoyarova, G. Rapid and tissue-specific changes in ABA and in growth rate in response to salinity in barley leaves. J. Exp. Bot. 2004, 55, 1115-1123. [CrossRef] [PubMed]

147. Tardieu, F.; Simonneau, T. Variability among species of stomatal control under fluctuating soil water status and evaporative demand: Modeling isohydric and anisohydric behaviours. J. Exp. Bot. 1998, 49, 419-432. [CrossRef]

148. Sánchez-Blanco, M.J.; Morales, M.A.; Torrecillas, A.; Alarcón, J.J. Diurnal and seasonal osmotic potential changes in Lotus creticus plants grown under saline stress. Plant Sci. 1998, 136, 1-10. [CrossRef]

149. Flexas, J.; Bota, J.; Loreto, F.; Cornic, G.; Sharkey, T.D. Diffusive and metabolic limitations to photosynthesis under drought and salinity in C3 plants. Plant Biol. 2004, 6, 269-279. [CrossRef] [PubMed]

150. Galle, A.; Florez-Sarasa, I.; Tomás, M.; Pou, A.; Medrano, H.; Ribas-Carbó, M.; Flexas, J. The role of mesophyll conductance during water stress and recovery in tobacco (Nicotiana sylvestris): Acclimation or limitation? J. Exp. Bot. 2009, 60, 2379-2390. [CrossRef] [PubMed]

151. Mugnai, S.; Ferrante, A.; Petrognani, L.; Serra, G.; Vernieri, P. Stres-Induced variation in leaf gas exchange and chlorophyll a fluorescence in Callistemon plants. Res. J. Biol. Sci. 2009, 4, 913-921.

152. Ali, A.; Iqbal, N.; Ali, F.; Afzal, B. Alternanthera bettzickiana (Regel.) G. Nicholson, a potential halophytic ornamental plant: Growth and physiological adaptations. Flora 2012, 207, 318-321. [CrossRef]

153. Chaves, M.M.; Osorio, J.; Pereira, J.S. Water use efficiency and photosynthesis. In Water Use Efficiency in Plant Biology; Bacon, M., Ed.; Blackwell Publishing: Oxford, UK, 2004; pp. 42-74.

154. James, R.A.; Rivelli, A.R.; Munns, R.; von Caemmerer, S. Factors affecting $\mathrm{CO}_{2}$ assimilation, leaf injury and growth in salt-stressed durum wheat. Funct. Plant Biol. 2002, 29, 1393-1403. [CrossRef]

155. Blum, A. Towards a conceptual ABA ideotype in plant breeding for water limited environments. Funct. Plant Biol. 2015, 42, 502-513. [CrossRef]

156. Chaves, M.M.; Costa, J.M.; Zarrouka, O.; Pinheiro, C.; Lopes, C.M.; Pereira, J.S. Controlling stomatal aperture in semi-arid regions-The dilemma of saving water or being cool? Plant Sci. 2016, 251, 54-64. [CrossRef] [PubMed]

157. Halim, R.A.; Buxton, D.R.; Hattendorf, M.J.; Carlson, R.E. Crop water-stress index and forage quality relationships in alfalfa. Agron. J. 1990, 82, 906-909. [CrossRef] 
158. Gerard, J.; Kluitenberg, J.; Biggar, W. Canopy temperature as a measure of salinity stress on sorghum. Irrig. Sci. 1992, 13, 115-121.

159. Sirault, X.R.R.; James, R.A.; Furbank, R.T. A new screening method for osmotic component of salinity tolerance in cereals using infrared thermography. Funct. Plant Biol. 2009, 36, 970-977. [CrossRef]

160. Gómez-Bellot, M.J.; Nortes, P.A.; Sánchez-Blanco, M.J.; Ortuño, M.F. Sensitivity of thermal imaging and infrared thermometry to detect water status changes in Euonymus japonica plants irrigated with saline reclaimedwater. Biosyst. Eng. 2015, 133, 21-32. [CrossRef]

161. Türkan, I.; Demiral, T. Recent developments in understanding salinity tolerance. Environ. Exp. Bot. 2009, 67, 2-9. [CrossRef]

162. Hare, P.D.; Cress, W.A.; van Staden, J. Proline synthesis and degradation: A model system for elucidating stress-related signal transduction. J. Exp. Bot. 1999, 50, 413-434. [CrossRef]

163. Kinnersley, A.M.; Turano, F.J. Gamma aminobutyric acid (GABA) and plant responses to stress. CRC Crit. Rev. Plant Sci. 2000, 19, 479-509. [CrossRef]

164. Zheng, Q.; Liu, Z.; Chen, G.; Gao, Y.; Li, Q.; Wang, J. Comparison of osmotic regulation in dehydration- and salinity-stressed sunflower seedlings. J. Plant Nutr. 2010, 33, 966-981. [CrossRef]

165. Suárez, N. Comparative leaf anatomy and pressure-volume analysis in plants of Ipomoea pes-caprae experimenting saline and/or drought stress. Int J. Bot. 2011, 7, 53-62. [CrossRef]

166. Mustard, J.; Renault, S. Effects of $\mathrm{NaCl}$ on water relations and cell wall elasticity and composition of red-osier dogwood (Cornus stolonifera) seedlings. Physiol. Plant. 2004, 121, 265-271. [CrossRef] [PubMed]

167. Sassi, S.; Aydi, S.; Hessini, K.; Gonzalez, E.M.; Arrese-Igor, C.; Abdelly, C. Long-term manitol-induced osmotic stress leads to stomatal closure, carbohydrate accumulation and changes in leaf elasticity in Phaseolus vulgaris leaves. Afr. J. Biotechnol. 2010, 9, 6061-6069.

168. Ashraf, M.; Fooland, M.R. Roles of glycine betaine and proline in improving plant abiotic stress resistance. Environ. Exp. Bot. 2007, 59, 206-216. [CrossRef]

169. Planchet, E.; Verdu, I.; Delahaie, J.; Cukier, C.; Girard, C.; Morère-Le Paven, M.C.; Limami, A.M. Abscisic acid-induced nitric oxide and proline accumulation in independent pathways under water-deficit stress during seedling establishment in Medicago truncatula. J. Exp. Bot. 2014, 65, 2161-2170. [CrossRef] [PubMed]

170. Szabados, L.; Savouré, A. Proline: A multifunctional amino acid. Trends Plant Sci. 2010, 15, 89-97. [CrossRef] [PubMed]

171. Wutipraditkul, N.; Wongwean, P.; Buaboocha, T. Alleviation of salt-induced oxidative stress in rice seedlings by proline and/or glycinebetaine. Biol. Plant. 2015, 59, 547-553. [CrossRef]

172. Jagendorf, A.T.; Takabe, T. Inducers of glycinebetaine synthesis in barley. Plant Physiol. 2001, 127, 1827-1835. [CrossRef] [PubMed]

173. Mäkelä, P.; Kärkkäinen, J.; Somersalo, S. Effect of glycinebetaine on chloroplast ultrastructure, chlorophyll and protein content, and Rubisco activities in tomato grown under drought or salinity. Biol. Plant 2000, 43, 471-475. [CrossRef]

174. Horei, T.; Karahara, I.; Katsuhara, M. Salinity tolerance mechanisms in glycophytes and overview central focus on rice plants. Rice 2012, 5, 11-18. [CrossRef] [PubMed]

175. Parida, A.; Das, A.B.; Das, $\mathrm{P}$. $\mathrm{NaCl}$ stress causes changes in photosynthetic pigments, proteins, and other metabolic components in the leaves of a true mangrove, Bruguiera parviflora, in hydroponic cultures. J. Plant Biol. 2002, 45, 28-36. [CrossRef]

176. Duarte, B.; Santos, D.; Marques, J.C.; Caçador, I. Ecophysiological adaptations of two halophytes to salt stress: Photosynthesis, PS II photochemistry and anti-oxidant feedback-Implications for resilience in climate change. Plant Physiol. Biochem. 2013, 67, 178-188. [CrossRef] [PubMed]

177. Chaves, M.M.; Flexas, J.; Pinheiro, C. Photosynthesis under drought and salt stress: Regulation mechanisms from whole plant to cell. Ann. Bot. 2009, 103, 551-560. [CrossRef] [PubMed]

178. Asada, K. The water-water cycle in chloroplasts: Scavenging of active oxygen and dissipation of excess photons. Ann. Rev. Plant Physiol. Plant Mol. Biol. 1999, 50, 601-639. [CrossRef] [PubMed]

179. Maxwell, K.; Johnson, G.N. Chlorophyll fluorescence: A practical guide. J. Exp. Bot. 2000, 51, 659-668. [PubMed]

180. Moradi, F.; Ismail, A.M. Responses of photosynthesis, chlorophyll fluorescence and ROS-scavenging systems to salt stress during seedling and reproductive stages in rice. Ann. Bot. 2007, 99, 1161-1179. [CrossRef] [PubMed] 
181. Lee, M.H.; Cho, E.J.; Wi, S.G.; Bae, H.; Kim, J.E.; Cho, J.Y.; Lee, S.; Kim, J.H.; Chung, B.Y. Divergences in morphological changes and antioxidant responses in salt-tolerant and salt-sensitive rice seedlings after salt stress. Plant Physiol. Biochem. 2013, 70, 325-335. [CrossRef] [PubMed]

182. Ikbal, F.; Hernández, J.A.; Barba-Espín, G.; Koussa, T.; Aziz, A.; Faize, M.; Diaz-Vivancos, P. Enhanced salt-induced antioxidative responses involve a contribution of polyamine biosynthesis in grapevine plants. J. Plant Physiol. 2014, 171, 779-788. [CrossRef] [PubMed]

183. Shu, S.; Yuan, L.Y.; Guo, S.R.; Sun, J.; Yuan, Y.H. Effects of exogenous spermine on chlorophyll fluorescence, antioxidant system and ultrastructure of chloroplasts in Cucumis sativus L. under salt stress. Plant Physiol. Biochem. 2013, 63, 209-216. [CrossRef] [PubMed]

184. Foyer, C.H.; Harbison, J. Oxygen metabolism and the regulation of photosynthetic electron transport. In Causes of Photooxidative Stresses and Amelioration of Defense Systems in Plants; Foyer, C.H., Mullineaux, P., Eds.; CRC Press: Boca Raton, FL, USA, 1994; pp. 1-42.

185. Demmig-Adams, B.; Adams, W.W., III. Photoprotection and other responses of plants to high light stress. Annu. Rev. Plant Physiol. Plant Mol. Biol. 1992, 43, 599-626. [CrossRef]

186. Zhang, Q.Y.; Wang, L.Y.; Kong, F.Y.; Deng, Y.S.; Li, B.; Meng, Q.W. Constitutive accumulation of zeaxanthin in tomato alleviates salt stress-induced photoinhibition and photooxidation. Physiol. Plant. 2012, 146, 363-373. [CrossRef] [PubMed]

187. Huang, C.; He, W.; Guo, J.; Chang, X.; Su, P.; Zhang, L. Increased sensitivity to salt stress in an ascorbate-deficient Arabidopsis mutant. J. Exp. Bot. 2005, 422, 3041-3049. [CrossRef] [PubMed]

188. Halliwell, B.; Gutteridge, J.M.C. Free Radicals in Biology and Medicine; Oxford University Press: London, UK, 2000.

189. Hodges, M.; Dellero, Y.; Keech, O.; Betti, M.; Raghavendra, A.S.; Sage, R.; Zhu, X.G.; Allen, D.K.; Weber, P.M. Perspectives for a better understanding of the metabolic integration of photorespiration within a complex plant primary metabolism network. J. Exp. Bot. 2016, 67, 3015-3026. [CrossRef] [PubMed]

190. Kangasjärvi, S.; Neukermans, J.; Li, S.; Aro, E.-M.; Noctor, G. Photosynthesis, photorespiration, and light signalling in defence responses. J. Exp. Bot. 2012, 63, 1619-1636. [CrossRef] [PubMed]

191. Corpas, F.J.; Gomez, M.; Hernández, J.A.; del Río, L.A. Metabolism of activated oxygen in peroxisomes from two Pisum sativum L. cultivars with different sensitivity to sodium chloride. J. Plant Physiol. 1993, 141, 160-165. [CrossRef]

192. Krall, J.P.; Edwards, G.E. Relationship between photosystem II activity and $\mathrm{CO}_{2}$ fixation in leaves. Physiol. Plant. 1992, 86, 180-187. [CrossRef]

193. Dat, J.; Vandenabeele, S.; Vranova, E.; Van Montagu, M.; Inzé, D.; Van Breusegem, F. Dual action of the active oxygen species during plant stress responses. Cell. Mol. Life Sci. 2000, 57, 779-795. [CrossRef] [PubMed]

194. Brisson, L.F.; Zelitch, I.; Havir, E.A. Manipulation of catalase levels produces altered photosynthesis in transgenic tobacco plants. Plant Physiol. 1998, 116, 259-269. [CrossRef] [PubMed]

195. Hernández, J.A.; Jiménez, A.; Mullineaux, P.M.; Sevilla, F. Tolerance of pea (Pisum sativum L.) to long-term salt stress is associated with induction of antioxidant defenses. Plant Cell Environ. 2000, 23, 853-862. [CrossRef]

196. Gómez, J.M.; Hernández, J.A.; Jiménez, A.; del Río, L.A.; Sevilla, F. Differential response of antioxidative enzymes of chloroplasts and mitochondria to long-term $\mathrm{NaCl}$ stress of pea plants. Free Rad. Res. 1999, 31, S11-S18. [CrossRef]

197. Mittova, V.; Tal, M.; Volokita, M.; Guy, M. Salt stress induces up-regulation of an efficient chloroplast antioxidant system in the salt-tolerant wild tomato species Lycopersicon pennellii but not in the cultivated species. Physiol. Plant. 2002, 115, 393-400. [CrossRef] [PubMed]

198. Rubio, M.C.; Bustos-Sanmaded, P.; Clemente, R.M.; Becana, M. Effects of salt stress on the expression of antioxidant genes and proteins in the model legume Lotus japonicus. New Phytol. 2009, 181, 851-859. [CrossRef] [PubMed]

199. Gueta-Dahan, Y.; Yaniv, Z.; Zilinskas, B.A.; Ben-Hayyim, G. Salt and oxidative stress: Similar and specific responses and their relation to salt tolerance in Citrus. Planta 1997, 203, 460-469. [CrossRef] [PubMed]

200. Tsugane, K.; Kobayashi, K.; Niwa, Y.; Ohba, Y.; Wada, K. A recessive Arabidopsis mutant that grows photoautotrophically under salt stress shows enhanced active oxygen detoxification. Plant Cell 1999, 11, 1195-1206. [CrossRef] [PubMed] 
201. López-Gómez, E.; Sanjuán, M.A.; Diaz-Vivancos, P.; Mataix-Beneyto, J.; García-Legaz, M.F.; Hernández, J.A. Effect of salinity and rootstocks on antioxidant systems of loquat plants (Eriobotrya japonica Lindl.): Response to supplementary boron addition. Environ. Exp. Bot. 2007, 160, 151-158. [CrossRef]

202. Leterrier, M.; Barroso, J.B.; Valderrama, R.; Palma, J.M.; Corpas, F.J. NADP-Dependent Isocitrate Dehydrogenase from Arabidopsis Roots Contributes in the Mechanism of Defence against the Nitro-Oxidative Stress Induced by Salinity. Sci. World. J. 2012, 2012, 694740. [CrossRef] [PubMed]

203. Meneguzzo, S.; Sgherri, C.L.M.; Navari-Izzo, F.; Izzo, R. Stromal and thylakoid-bound ascorbate peroxidase in NaCl-treated wheat. Physiol. Plant. 1998, 104, 735-740. [CrossRef]

204. Qiu-Fang, Z.; Yuan-Yuan, L.; Cai-Hong, P.; Cong-Ming, L.; Bao-Shan, W. NaCl enhances thylakoid-bound SOD activity in the leaves of C3 halophyte Suaeda salsa L. Plant Sci. 2005, 168, 423-430. [CrossRef]

205. Gómez, J.M.; Jiménez, A.; Olmos, E.; Sevilla, F. Location and effects of long-term $\mathrm{NaCl}$ stress on superoxide dismutase and ascorbate peroxidase isoenzymes of pea (Pisum sativum cv. Puget) chloroplasts. J. Exp. Bot. 2004, 55, 119-130. [CrossRef] [PubMed]

206. Mutlu, S.; Atici, Ö.; Nalbantoglu, B. Effects of salicylic acid and salinity on apoplastic antioxidant enzymes in two wheat cultivars differing in salt tolerance. Biol. Plant. 2009, 53, 334-338. [CrossRef]

207. Diaz-Vivancos, P.; Faize, M.; Barba-Espin, G.; Faize, L.; Petri, C.; Hernández, J.A.; Burgos, L. Ectopic expression of cytosolic superoxide dismutase and ascorbate per-oxidase leads to salt stress tolerance in transgenic plums. Plant Biotechnol. 2013, 11, 976-985. [CrossRef] [PubMed]

208. Fernández-García, N.; Hernández, M.; Casado-Vela, J.; Bru, R.; Elortza, F.; Hedden, P.; Olmos, E. Changes to the proteome and targeted metabolites of xylem sap in Brassica oleracea. Plant Cell Environ. 2011, 34, 821-836. [CrossRef] [PubMed]

209. Hideg, E.; Barta, C.; Kalai, T.; Vass, M.; Hideg, K.; Asada, K. Detection of singlet oxygen and superoxide with fluorescence sensors in leaves under stress by photoinhibition or UV radiation. Plant Cell Physiol. 2002, 43, 1154-1164. [CrossRef] [PubMed]

210. Boveris, A. Determination of the production of superoxide radicals and hydrogen peroxide in mitochondria. Methods Enzymol. 1984, 105, 429-435. [PubMed]

211. Schmitt, N.; Dizengremel, P. Effect of osmotic stress on mitochondria isolated from etiolated mung bean and sorghum seedlings. Plant Physiol. Biochem. 1989, 27, 17-26.

212. del Río, L.A.; Pastori, G.M.; Palma, J.M.; Sandalio, L.M.; Sevilla, F.; Corpas, F.J.; Jiménez, A.; López-Huertas, E.; Hernández, J.A. The activated oxygen role of peroxisomes in senescence. Plant Physiol. 1998, 116, 1195-1200.

213. Zelitch, I.; Schultes, N.P.; Peterson, R.B.; Brown, P.; Brutnell, T.P. High glycolate oxidase activity is required for survival of maize in normal air. Plant Physiol. 2009, 149, 195-204. [CrossRef] [PubMed]

214. del Río, L.A.; Sandalio, L.M.; Altomare, D.A.; Zilinskas, B.A. Mitochondrial and peroxisomal manganese superoxide dismutase: Differential expression during leaf senescence. J. Exp. Bot. 2003, 54, 923-933.

215. Bellicampi, D.; Dipierro, N.; Salvi, G.; Cervone, F.; De Lorenzo, G. Extracellular $\mathrm{H}_{2} \mathrm{O}_{2}$ induced by oligogalacturonides is not involved in the inhibition of the auxin-regulated roIB gene expression in tobacco leaf explants. Plant Physiol. 2000, 122, 1379-1385. [CrossRef]

216. García de la Garma, J.; Fernández.-García, N.; Bardasi, E.; Pallol, B.; Asensio-Rubio, J.S.; Olmos, E. New insights into plant salt acclimation: The roles of vesicle trafficking and reactive oxygen species signalling in mitochondria and the endomembrane system. New Phytol. 2015, 205, $216-239$.

217. Wang, R.; Chen, S.; Zhou, X.; Shen, X.; Deng, L.; Zhu, H.; Shao, J.; Shi, Y.; Dai, S.; Fritz, E.; Hüttermann, A.; Polle, A. Ionic homeostasis and reactive oxygen species control in leaves and xylem sap of two poplars subjected to $\mathrm{NaCl}$ stress. Tree Physiol. 2008, 28, 947-957. [CrossRef] [PubMed]

218. Dinler, B.S.; Antoniou, C.; Fotopoulos, V. Interplay between GST and nitric oxide in the early response of soybean (Glycine max L.) plants to salinity stress. J. Plant Physiol. 2014, 171, 1740-1747. [CrossRef] [PubMed]

219. Kaur, H.; Bhatla, S.C. Melatonin and nitric oxide modulate glutathione content and glutathione reductase activity in sunflower seedling cotyledons accompanying salt stress. Nitric Oxide 2016, 59, 42-53. [CrossRef] [PubMed]

220. Manai, J.; Gouia, H.; Corpas, F.J. Redox and nitric oxide homeostasis are affected in tomato (Solanum lycopersicum) roots under salinity-induced oxidative stress. J. Plant Physiol. 2014, 171, 1028-1035. [CrossRef] [PubMed] 
221. Corpas, F.J.; Hayashi, M.; Mano, S.; Nishimura, M.; Barroso, J.B. Peroxisomes are required for in vivo nitric oxide accumulation in the cytosol following salinity stress of Arabidopsis plants. Plant Physiol. 2009, 151, 2083-2094. [CrossRef] [PubMed]

222. Valderrama, R.; Corpas, F.J.; Carreras, A.; Fernández-Ocaña, A.; Chaki, M.; Luque, F.; Gómez-Rodríguez, M.V.; Colmenero-Varea, P.; del Río, L.A.; Barroso, J.B. Nitrosative stress in plants. FEBS Lett. 2007, 581, $453-461$. [CrossRef] [PubMed]

223. Hossain, M.A.; Bhattacharjee, S.; Armin, S.M.; Qian, P.; Xin, W.; Li, H.Y.; Burritt, D.J.; Fujita, M.; Tran, L.S.P. Hydrogen peroxide priming modulates abiotic oxidative stress tolerance: Insights from ROS detoxification and scavenging. Front. Plant Sci. 2015, 6, 420. [CrossRef] [PubMed]

224. Li, C.; Wang, P.; Wei, Z.; Liang, D.; Liu, C.; Yin, L.; Jia, D.; Fu, M.; Ma, F. The mitigation effects of exogenous melatonin on salinity-induced stress in Malus hupehensis. J. Pineal Res. 2012, 53, 298-306. [CrossRef] [PubMed]

225. He, Y.; Zhu, Z.J. Exogenous salicylic acid alleviates $\mathrm{NaCl}$ toxicity and increases antioxidative enzyme activity in Lycopersicon esculentum. Biol. Plant. 2008, 52, 792-795. [CrossRef]

226. Bastam, N.; Baninasab, B.; Ghobadi, C. Improving salt tolerance by exogenous application of salicylic acid in seedlings of pistachio. Plant Growth Regul. 2013, 69, 275-284. [CrossRef]

227. Borsani, O.; Valpuesta, V.; Botella, M.A. Evidence for a role of salicylic acid in the oxidative damage generated by $\mathrm{NaCl}$ and osmotic stress in Arabidopsis seedlings. Plant Physiol. 2001, 126, 1024-1030. [CrossRef] [PubMed]

228. Nahar, K.; Hasanuzzaman, M.; Rahman, A.; Alam, M.M.; Mahmud, J.A.; Suzuki, T.; Fujita, M. Polyamines confer salt tolerance in mung bean (Vigna radiata L.) by reducing sodium uptake, improving nutrient homeostasis, antioxidant defense, and methylglyoxal detoxification systems. Front. Plant Sci. 2016, 7, 1104. [CrossRef] [PubMed]

(C) 2017 by the authors. Licensee MDPI, Basel, Switzerland. This article is an open access article distributed under the terms and conditions of the Creative Commons Attribution (CC BY) license (http:/ / creativecommons.org/licenses/by/4.0/). 